\title{
Aerosol composition of the tropical upper troposphere
}

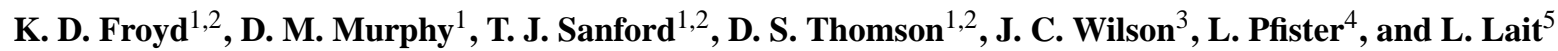 \\ ${ }^{1}$ NOAA Earth System Research Laboratory, Chemical Sciences Division, Boulder, CO, USA \\ ${ }^{2}$ Cooperative Institute for Research in Environmental Science, University of Colorado, Boulder, CO, USA \\ ${ }^{3}$ Department of Mechanical and Materials Engineering, University of Denver, Denver, CO, USA \\ ${ }^{4}$ NASA Ames Research Center, Moffett Field, CA, USA \\ ${ }^{5}$ Goddard Earth Sciences and Technology Center, University of Maryland Baltimore County, Baltimore, MD, USA
}

Received: 25 March 2009 - Published in Atmos. Chem. Phys. Discuss.: 9 April 2009

Revised: 25 June 2009 - Accepted: 26 June 2009 - Published: 7 July 2009

Abstract. Aerosol composition was measured by the NOAA single-particle mass spectrometer (PALMS) aboard the NASA WB-57 high altitude aircraft platform during two Aura Validation Experiment (AVE) campaigns based in Costa Rica in 2004 and 2006. These studies yielded the most complete set of aerosol composition measurements to date throughout the tropical tropopause layer (TTL) and tropical lower stratosphere. We describe the aerosol properties of the tropical atmosphere and use composition tracers to examine particle sources, the role of recent convection, and cirrus-forming potential in the TTL. Tropical dynamics and regional air sources played principal roles in dictating tropospheric aerosol properties. There was a sharp change in aerosol chemical composition at about $12 \mathrm{~km}$ altitude coincident with a change in convective influence. Below this level, maritime convection lofted condensable material that generated acidic, sulfate-rich aerosol. These particles contained significant amounts of methanesulfonic acid (MSA) and showed evidence of cloud processes. In contrast, continental convection injected particles and precursors directly into the TTL, yielding a population of neutralized, organic-rich aerosol. The organics were often highly oxidized and particles with oxidized organics also contained nitrate. Above the tropopause, chemical composition gradually changed toward sulfuric acid particles but neutralized particles were still abundant $2 \mathrm{~km}$ above the tropopause. Deep continental convection, though sporadic and geographically localized, may strongly influence TTL aerosol properties on a global scale. The abundance of organic-rich aerosol may inhibit ice nucleation and formation of tropopause level cirrus.

Correspondence to: K. D. Froyd (karl.froyd@noaa.gov)

\section{Introduction}

The tropical tropopause layer (TTL) is the region connecting convectively active levels of the tropical troposphere to the stratosphere (e.g., Folkins et al., 1999, 2000; Highwood and Hoskins, 1998). The bottom of the TTL is usually defined as either the level where large scale convective outflow declines (potential temperature $\theta \approx 350 \mathrm{~K}, 12-13 \mathrm{~km}$ ) or the level of net zero radiative heating $(360 \mathrm{~K}, 14 \mathrm{~km})$. The thermal tropopause is located around $380 \mathrm{~K}(17 \mathrm{~km})$ and by some definitions is contained within the TTL (for this study we distinguish between the TTL and the lower stratosphere). At the $350 \mathrm{~K}$ level and below, vertical transport is driven by convection. Convective outflow decreases rapidly above this level but is still sporadic at e.g., $360 \mathrm{~K}$ (Folkins et al., 2000; Gettelman et al., 2004; Park et al., 2007). Above this level, the overriding ascent mechanism in the TTL is large scale, radiatively driven upwelling. Convection has been observed higher into the TTL as well (Alcala and Dessler, 2002; Knollenberg et al., 1993; Hong et al., 2007; Liu, 2007), but this mechanism is rare and some models report that deep convection has a small direct impact on vertical mass transport into and across the tropopause region (Folkins, 2002; Gettelman et al., 2002; Kupper et al., 2004).

The tropical upper troposphere is a conduit for air entering the stratosphere, providing the supply for the BrewerDobson circulation. As such, chemical processes occurring in the TTL help define the composition of the global stratosphere. The importance of aerosol in the upper troposphere is twofold. Aerosols that cross the tropopause bring condensed material to the lower stratosphere as well as provide a surface for condensation of sulfuric acid (e.g., Brock et al., 1995). TTL aerosols may also affect the transport of water vapor and semi-volatile trace gases across the tropopause by regulating cirrus cloud formation.

Published by Copernicus Publications on behalf of the European Geosciences Union. 
Subvisible cirrus are unique, optically thin clouds that form at the cold temperatures near the tropical tropopause. These low density clouds can be widespread (Wang et al., 1996; Winker and Trepte, 1998; Pfister et al., 2001; Dessler and Yang, 2003; Dessler et al., 2006) and may have an appreciable impact on global radiative balance (McFarquhar et al., 2000; Wang et al., 1996). They also play a critical role in water vapor transport into the stratosphere by increasing tropopause temperatures (Rosenfield et al., 1998) and dehydrating the upwelling air (Jensen et al., 1996; Jensen and Pfister, 2004; Luo et al., 2003; Holton and Gettelman, 2001). TTL cirrus form in situ via freezing of ambient aerosol, but the nucleation mechanism is currently unknown. In other regions of the troposphere, the onset of ice crystal formation was shown to be strongly influenced by aerosol size and composition (Cziczo et al., 2004a, b; Archuleta et al., 2005). Descriptions of TTL aerosol may help identify cirrus formation mechanisms and improve our predictive capability for these important atmospheric features.

Aerosol properties of the TTL and tropical lower stratosphere are relatively uncharacterized because of the limited number of research platforms and instruments capable of sampling at these altitudes. However, several groups have measured bulk aerosol composition in the remote tropics at levels below the TTL (see Ma et al., 2004). Dibb et al. (1999, 2003) measured water soluble ionic species by ion chromatography analysis of aerosol material collected on filters. The Particle-into-Liquid Sampler (PILS) was also used for online chemical characterization of inorganic material (Lee et al., 2003). Above the marine boundary layer, aerosol inorganic components were predominantly sulfate, either partially or fully neutralized by ammonium $\left(\mathrm{NH}_{4}^{+}: \mathrm{SO}_{4}^{2-}\right.$ typically 1-2). Substantial quantities of mineral dust, nitrate, and other continental material were also observed in regions of Asian outflow. Organic material was not quantified.

Single particle composition measurements are less quantitative than these methods, but the PALMS instrument provides information on particle mixing state and composition markers for specific particle types. Single particle information is particularly important for studying ice nucleation, where a minor aerosol subpopulation with distinct composition can dictate cloud properties. In previous PALMS measurements in mid-latitude and sub-tropical regions, internal mixtures of sulfate and carbonaceous material, mostly organic carbon, comprised a large fraction of accumulation mode aerosol number and mass in the free troposphere and lower stratosphere (Murphy et al., 2006, 2007a). Many other particles types such as biomass burning, mineral dust, and sea salt are commonly observed.

A few other in situ measurements of single particle composition have been reported in the tropical upper troposphere, but measurements are limited to a small number of captured particles that are analyzed offline. Recently, Nguyen et al. (2008) performed PIXE elemental analysis on individual particles collected at $10 \mathrm{~km}$ altitude during a transcontinen- tal flight. Morphological analysis of the dominant sulfateorganic particle type suggests that the sulfate and organic material may not be mixed homogeneously within individual particles. In early stratospheric work, Bigg (1986) and Gras (1978) used a balloon-borne aerosol collection instrument to infer individual particle composition, specifically neutralization of sulfuric acid aerosol by ammonium, from single particle impaction patterns. Most particles were liquid sulfuric acid, but under some conditions they observed impaction patterns consistent with solid particles, which the authors attributed to ammonium bisulfate or ammonium sulfate.

We present airborne measurements of tropical aerosol composition and size extending from ground level to the lower stratosphere. Measurements were performed during the Pre-Aura Validation Experiment and the Costa Rica Aura Validation Experiment (Pre-AVE and CR-AVE) in JanuaryFebruary 2004 and 2006, respectively. The NASA WB-57 aircraft was based in San Jose, Costa Rica, carrying a remote sensing and in situ chemical instrumentation payload. The aircraft typically operated southwest of Central America, and the majority of flight time was spent within a few $\mathrm{km}$ of the tropopause, often in cloud-free air. These flights enabled the most comprehensive measurements to date of aerosol composition and size distributions in the tropical tropopause layer. We discuss these results with special emphasis on the TTL and the regions supplying it.

\section{Measurements}

The PALMS instrument is a single particle mass spectrometer capable of determining aerosol composition and aerodynamic diameter on a particle-by-particle basis. The flight version of PALMS is described in Thomson et al. (2000), and recent inlet and particle sizing modifications are summarized in Murphy et al. (2006). In the NASA WB-57 configuration PALMS samples aerosol particles using a forward facing inlet that is housed at the center of a $5 \mathrm{~cm}$ i.d. duct protruding from the nose of the aircraft. The Pre-AVE inlet was a simple nozzle with a $1.50 \mathrm{~mm}$ i.d. During CR-AVE a $4.0 \mathrm{~mm}$ i.d. combination aerosol and counterflow virtual impactor inlet (Cziczo et al., 2004b) was used. Particle residence times within the inlets and connective tubing were about $70 \mathrm{~ms}$ for both campaigns when sampling in ambient aerosol mode. The Pre-AVE inlet enhanced particle collection for diameters greater than $\sim 0.8 \mu \mathrm{m}$, elevating observed number fractions of sea salt and mineral dust by as much as a factor of 2 over CR-AVE. Downstream of the inlet, particles pass through a $300 \mu \mathrm{m}$ critical orifice and a series of focusing stages. Then in an evacuated region, a particle will scatter light from two consecutive $532 \mathrm{~nm}$ Nd:YAG beams, where its aerodynamic diameter is measured. A scattering event at the second beam triggers a pulse from a $193 \mathrm{~nm}$ excimer laser that vaporizes and ionizes the particle. Ions are extracted using a static electric field and analyzed with a time-of-flight 
mass spectrometer, yielding one positive or negative spectrum per particle. Particles as small as $200 \mathrm{~nm}$ diameter are observed with low efficiency $(<1 \%)$. Detection efficiency increases rapidly with size above $\sim 500 \mathrm{~nm}$ so that $>25 \%$ of $1 \mu \mathrm{m}$ particles are detected. PALMS samples only a fraction of a typical aerosol number concentration, but in most regions the PALMS size range encompasses the majority of the aerosol mass. In the tropical upper troposphere the average size can be small so PALMS detected particles in the upper $20-40 \%$ of the mass range.

The PALMS single particle technique is especially well suited to distinguishing different aerosol types. Hudson et al. (2004) developed selection criteria for aerosol particles generated by biomass burning based on the appearance and relative intensities of specific peaks in aerosol mass spectra. Using similar methodology, we present data products for other common particle types: sea salt, mineral dust, meteoric material, elemental carbon, and sulfate-organic internal mixtures. These broad aerosol types are most effectively differentiated using positive ion spectra. Although negative ion spectra can differentiate some types (e.g., mineral dust and sulfate-organic aerosols), other aerosols are indistinguishable (biomass burning and sulfate-organic mixtures). Only positive spectra are used here for the aerosol type data products. Biomass burning spectra are unique in that a prominent $\mathrm{K}^{+}$ peak is present along with organic material (primarily $\mathrm{C}^{+}$ and $\mathrm{CO}^{+}$with many other fragments) with a lack of other metals. Mineral dust spectra contain high intensity peaks of $\mathrm{Fe}^{+}, \mathrm{K}^{+}, \mathrm{Ca}^{+}$, and $\mathrm{Na}^{+}$metal ions, along with minor contributions from $\mathrm{Al}^{+}, \mathrm{Si}^{+}, \mathrm{Mg}^{+}, \mathrm{Rb}^{+}, \mathrm{Ba}^{+}$, and a number of other trace metals. Aerosols containing meteoric material produce $\mathrm{Fe}^{+}$and $\mathrm{Mg}^{+}$metal ions at a unique ratio $(\mathrm{Cz}-$ iczo et al., 2001). Sea salt spectra show a dominant $\mathrm{Na}^{+}$ peak without $\mathrm{Fe}^{+}, \mathrm{Al}^{+}$, or $\mathrm{Ba}^{+}$metals, and usually include $\mathrm{Ca}^{+}, \mathrm{K}^{+}, \mathrm{Sr}^{+}$, and chloride or sodium sulfate peaks, $\mathrm{CaCl}^{+}$ or $\mathrm{Na}_{3} \mathrm{SO}_{4}^{+}$. Elemental carbon spectra have distinct $\mathrm{C}_{n}^{+}$and $\mathrm{C}_{n} \mathrm{H}^{+}$series, $n \geq 6$. Aerosols from industrial sources have intense ion signatures from combinations of $\mathrm{V}^{+}, \mathrm{Sn}^{+}, \mathrm{Sb}^{+}$, and $\mathrm{Pb}^{+}$without typical mineral dust peaks. Spectra are labeled as internally mixed sulfate-organic aerosols where none of the other aerosol types are chosen and the majority of ion current is due to common organic and sulfate $\left(\mathrm{SO}_{2}^{+}\right.$, $\mathrm{H}_{\mathrm{x}} \mathrm{SO}_{3}^{+}$, and $\mathrm{H}_{3} \mathrm{SO}_{4}^{+}$) peaks. After processing all spectra using these selection criteria, spectra that cannot be confirmed as any of the above aerosol types are labeled unidentified.

A particle spectrum is given only one aerosol type. Chemical transformations can blur the distinctions between aerosol types, e.g., sulfate accumulation onto mineral dust. In such cases aerosols are identified according to their primary or most relevant component, e.g., sulfate-coated dust is labeled as mineral dust for any spectrum where the appropriate metal signatures are above detection limits. Elemental carbon is often not clearly distinguished when internally mixed with sulfate-organic or biomass burning aerosols. The EC data product presented here is therefore an indication aerosols with a high mass fraction of elemental carbon without detectable biomass material. A cluster analysis routine (Murphy et al., 2003) that groups particle types based on spectral similarities is a complementary technique that requires no a priori assumptions about chemical signatures, but was not used directly in generating aerosol type data products.

Besides qualitative particle type, we also use relative ion intensities to determine the abundance of specific aerosol components. The laser ablation-ionization process yields relative ion intensities that are highly variable particle-toparticle. However, PALMS can give quantitative estimates for some particle components given a sufficient sample set. Of particular value is the ability to examine the chemistry of a certain particle type. For instance the relative mass fraction of sulfate versus organic material in internally mixed sulfate-organic particles was recently estimated (Murphy et al., 2006). PALMS negative ion sulfate and organic signals were calibrated to Aerosol Mass Spectrometer mass fractions using lower tropospheric particles measured during the Intercontinental Transport and Chemical Transformation-New England Air Quality Study (ITCT-NEAQS 2004). Biomass burning particles are inherently included in this calculation since they are difficult to differentiate from sulfate-organic mixtures in negative ion spectra.

Sulfate acidity is estimated here based on in-field calibrations with the Particle-into-Liquid Sampler (PILS) during NEAQS-ITCT 2004 (Peltier et al., 2007). In negative ion spectra, the prominent $\mathrm{HSO}_{4}^{-}$peak $(\mathrm{m} / \mathrm{z} / 97)$ is independent of sulfate acidity, but the $\mathrm{HSO}_{4}^{-}\left(\mathrm{H}_{2} \mathrm{SO}_{4}\right)$ cluster ion (195) appears only for acidic particles. The cluster is probably generated from $\mathrm{HSO}_{4}^{-}$ions within the particle but is not produced from $\mathrm{SO}_{4}^{2-}$. In ammonium-sulfuric acid solutions, for ratios $\mathrm{NH}_{4}^{+}: \mathrm{SO}_{4}^{2-} \leq 1$ sulfate is predominantly $\mathrm{HSO}_{4}^{-}(\mathrm{aq})$. As $\mathrm{NH}_{4}^{+}: \mathrm{SO}_{4}^{2-}$ increases to $2, \mathrm{HSO}_{4}^{-}$is converted to $\mathrm{SO}_{4}^{2-}$. Figure 1 is an acidity calibration plot using the relative cluster ion peak intensity. During ITCT-NEAQS, sulfate was often fully neutralized, and the majority of spectra had no cluster ion peak. In the atmosphere, aerosol acidity is principally determined by sulfate and ammonium, but the presence of amines, organic acids, nitric acid, and S(IV) species in aerosol can also affect acidity. These species are not explicitly considered in this calibration. The 195/97 peak ratios also vary with laser power. Only spectra taken at full laser power (3-4 mJ/pulse) are considered.

A similar acidity feature is observed in positive spectra. Mass $48\left(\mathrm{SO}^{+}\right)$is a general sulfate signature, whereas intensity of mass $99\left(\mathrm{H}_{3} \mathrm{SO}_{4}^{+}\right)$correlates with sulfate acidity. Ammonium does not give a clear signature in positive spectra. Ammonium, nitrate, and other nitrogen species are all predominantly converted to $\mathrm{NO}^{+}$. However, the ratio of $\mathrm{m} / z .17$ to $(17+18)$ or $(17+19)$ correlates with ammonium abundance in atmospheric and laboratory particles. Presumably, mass 17 is due mostly to the $\mathrm{NH}_{3}^{+}$ion with some $\mathrm{OH}^{+}, 18$ is 


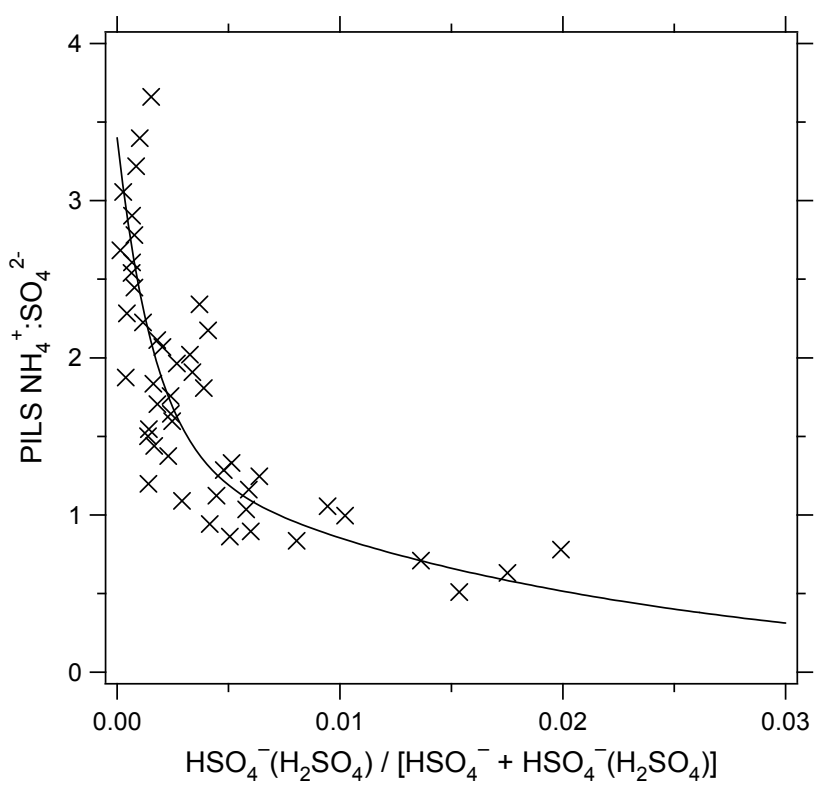

Fig. 1. PALMS acidity parameter for sulfate-organic particles calibrated to PILS NH ticles measured during the ITCT/New England Air Quality Study 2004. Each point represents average intensity ratio for 1000 particle spectra. The calibration line is a double exponential empirical fit to the data. PALMS peak ratios above 0.1 are truncated to limit the influence of a few spectra with a very high cluster peak. PILS data are considered for times when both $\mathrm{NH}_{4}^{+}$and $\mathrm{SO}_{4}^{2-}$ were above their detection limits. In-cloud sampling has been removed.

both $\mathrm{H}_{2} \mathrm{O}^{+}$and $\mathrm{NH}_{4}^{+}$, and 19 is $\mathrm{H}_{3} \mathrm{O}^{+}$. The $\mathrm{H}_{3} \mathrm{SO}_{4}^{+}$and $\mathrm{NH}_{3}^{+}$peak heights are broadly consistent with the negative cluster ion signature and support the acidity estimates presented here. However, the positive ion signatures are more strongly influenced by water content, organics, and trace metals. Therefore, sulfate acidity estimates are calculated using only negative spectra.

The Nucleation Mode Aerosol Sizing Spectrometer (NMASS) instrument (Brock et al., 2000) is an array of 5 condensation particle counters from which $4-100 \mathrm{~nm}$ size distributions are determined. The Focused Cavity Aerosol Spectrometer (FCAS II) instrument (Jonsson et al., 1995; Wilson et al., 2008) uses light scattered from a laser to measure aerosol size for dry diameters $100<D_{p}<1000 \mathrm{~nm}$. Concentrations are adjusted to account for the effects of anisokinetic sampling.

\section{Meteorological context}

\subsection{Air mass history}

In the 2004 Pre-AVE and 2006 CR-AVE campaigns, the WB57 sampled a region bounded roughly by $5 \mathrm{~S}$ to $20 \mathrm{~N}$ latitude, and $95 \mathrm{~W}$ to $75 \mathrm{~W}$ longitude. The vertical thermal struc- ture of the atmosphere over this region was very similar between the two campaign periods. The average tropopause height was about the same, with the thermal tropopause for CR-AVE being very slightly higher (16.9 km compared to $16.5 \mathrm{~km}$ for Pre-AVE). Both missions took place during the easterly phase of the quasi-biennial oscillation at $70 \mathrm{hPa}$, and at stratospheric levels the zonal winds in the sampling region were indeed easterly. However, at TTL flight altitudes near the $365 \mathrm{~K}$ isentropic surface, a westerly jet was observed during the CR-AVE period, while during the Pre-AVE period the winds were weakly easterly. Examination of 19802006 statistics for the eastern Pacific using the NCEP-NCAR reanalysis products (Fig. 2a) reveals that the westerly flow at $365 \mathrm{~K}$ was unusually strong during most of the CR-AVE campaign. The westerly flow in the eastern Pacific during CR-AVE seems to have been an extension of the Walker circulation further east than usual.

Quasi-isentropic back-trajectory calculations from the WB-57 flight track, as well as gridded kinematic backtrajectories over the region (Fig. 2b), confirm the origin of sampled air. During Pre-AVE, TTL air encountered by the WB-57 came largely from the South America Amazonia region over the previous five days, while air encountered during CR-AVE typically came from the mid-Pacific over comparable time periods. Even at higher flight altitudes where the winds were easterly, sampled parcels generally came from far northern South American rather than Amazonia over the previous five days (and from the eastern Pacific during the previous ten days). The zonal wind patterns and trajectories at lower levels $(350 \mathrm{~K})$ were broadly similar to $365 \mathrm{~K}$ but with a higher fraction of trajectories originating in the Pacific for both years. One would therefore expect that measurements taken during the 2004 campaign would exhibit influences of Amazonian convection, and that these influences would be much less prevalent in measurements from the 2006 campaign.

\subsection{Convective influence}

The back trajectories and time-averaged picture of winds shown in Fig. 2 yield an overall notion of the origin of the air sampled by the WB-57 in Central America during the PreAVE and CR-AVE winter periods. However, since both convection and winds have substantial time variability, a more comprehensive approach is needed to establish the origin of the sampled air.

In the troposphere below the TTL, convective turnover times are generally short (a week or so), and air descends slowly between convective systems. Within the TTL, air ascends and convective turnover times lengthen. Notably, though most convection does not penetrate the TTL, it is still significant, because even occasional convection can compete with the slow transit time from the bottom of the TTL to the tropopause. An important point here is that the convection that is most likely to penetrate into the TTL is not uniformly 
(a) REAN2 @ 365.0 K, 1980--2003 \& 2005--2006

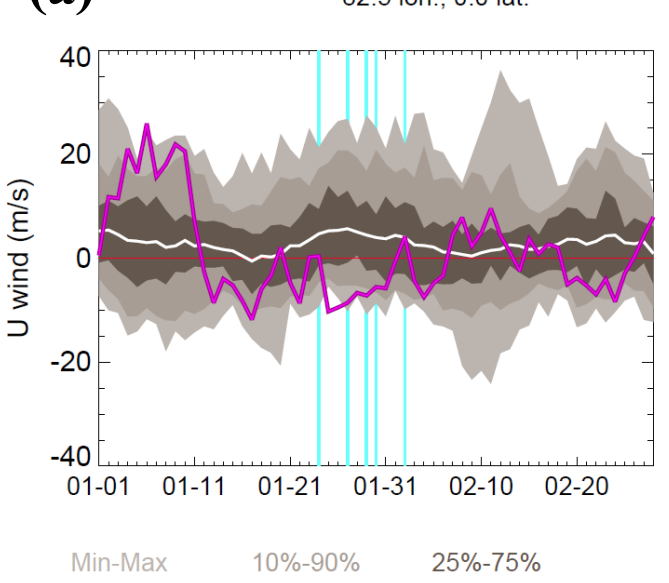

(b)

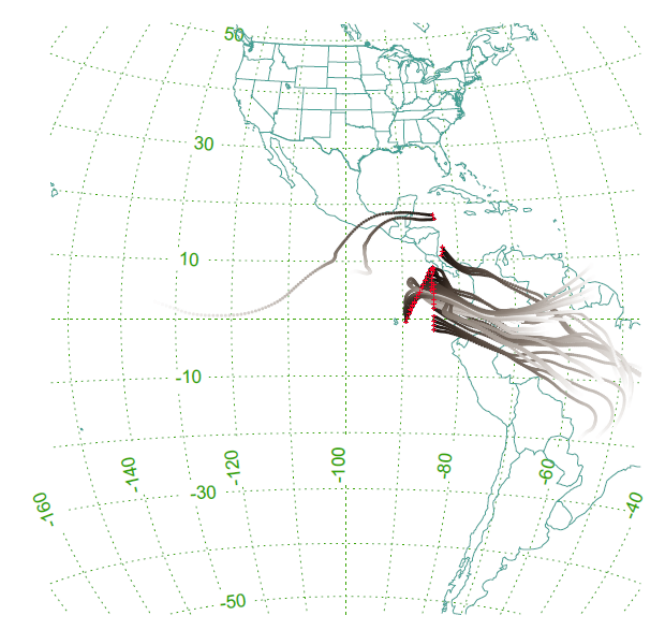

REAN2 @ 365.0 K, 1980--2005 -82.5 lon., 0.0 lat.
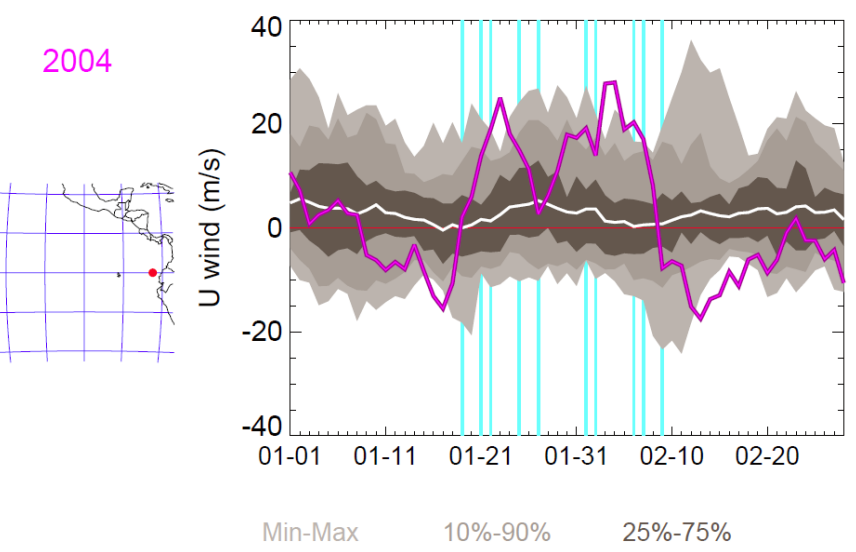

2006

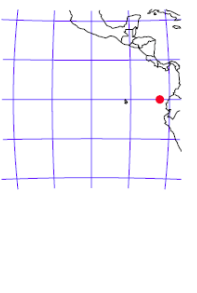

CR-AVE (2006)

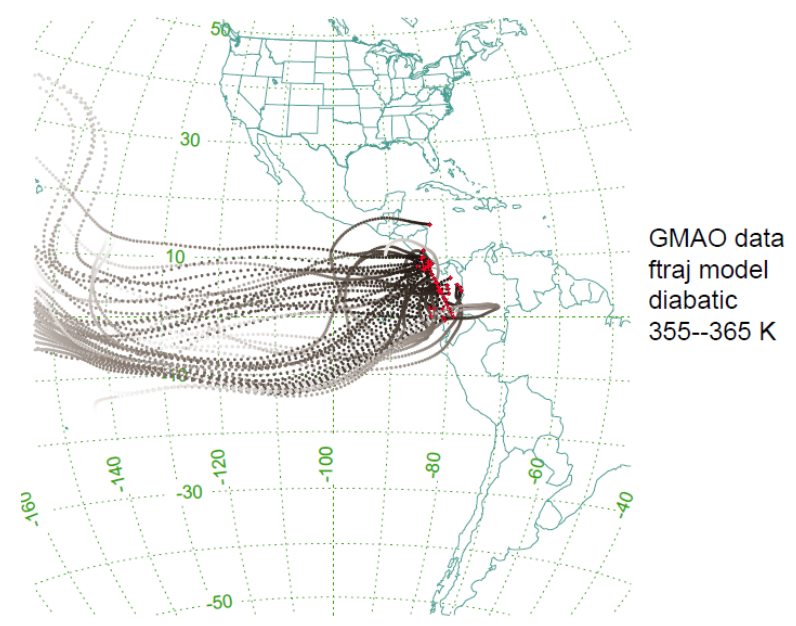

Fig. 2. (a) TTL zonal wind statistics $(\theta=365 \mathrm{~K})$ for January and February 1980-2006 at $82.5 \mathrm{~W}$ longitude and 0 latitude, compared to winds for the Pre-AVE and CR-AVE campaign years (magenta lines). The light gray envelope marks the min and max wind values from 1980 through 2006, the slightly darker gray marks the envelope of the tenth to ninetieth percentiles, and the dark gray marks the envelope of the twenty-fifth to seventy-fifth percentiles. The white line marks the median wind values. WB-57 flight days are shown as vertical lines in cyan. (b) Sources of air to the lower TTL. Maps show five-day kinematic back-trajectories from representative air parcels sampled along the WB-57's flight tracks. Parcels having potential temperatures 355-365 K were selected; their sampled positions along the flights are shown in red. Trajectories are color-coded by age; the closer to the sampling time, the darker they appear.

distributed among convective regions. Oceanic convection in the tropics is typically less intense than over the continents (Toracinta et al., 2002) and is less likely to penetrate the TTL (Alcala and Dessler, 2002). Liu and Zipser (2005) found that the deepest convection was located over the continents of South America and Africa. Penetrations to high altitudes $(16-18 \mathrm{~km})$ have also been found in northern Australia (Danielsen, 1993; Kritz et al., 1993), and over tropical cyclones (Kelly et al., 1993; Pfister et al., 1993).

In this context, we seek to learn: (1) what fraction of the air at different altitudes has a recent convective origin?; (2) what is the location of the convection?; and (3) how re- cent is it? We use a trajectory-based approach that traces air masses observed by the aircraft back to convective systems (Pfister et al., 2001). 14 day back trajectories were calculated from a cluster of points surrounding aircraft samples every $\sim 30 \mathrm{~km}$ along the flight path (more frequently when the aircraft was ascending or descending). Effectively, each of these aircraft samples was represented by a cluster of 15 points at three different altitudes bracketing the aircraft. Using clusters helps characterize the effect of trajectory errors. Air was labeled convectively influenced when a trajectory encountered a cloud whose top was higher than the parcel trajectory (where the cloud top was based on the brightness 


\section{(a) Pre-AVE 2004}
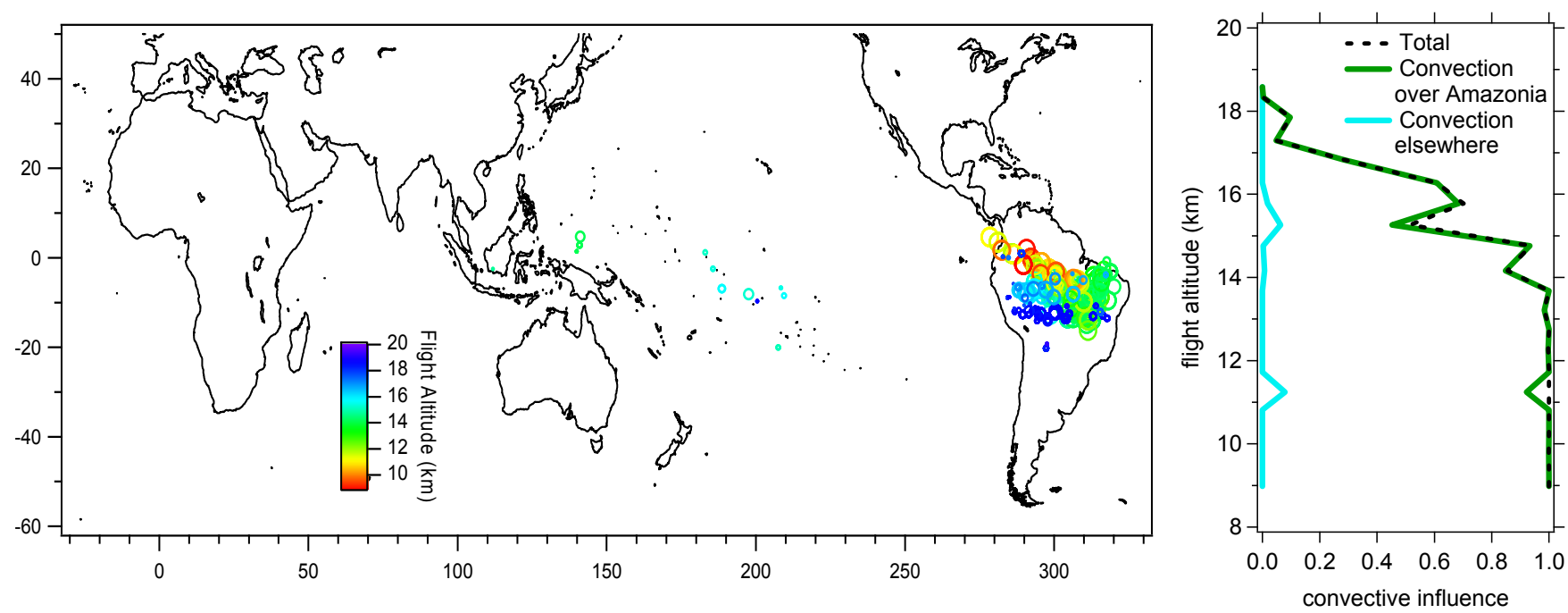

(b) CR-AVE 2006
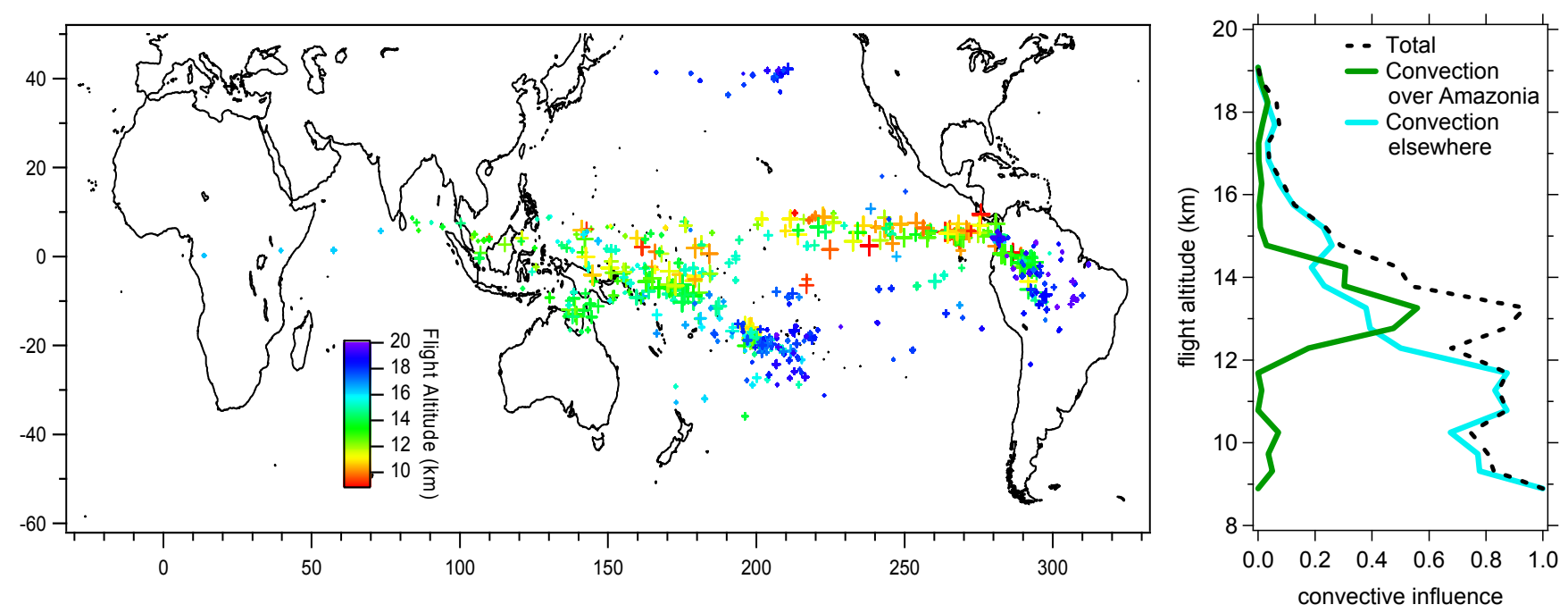

Fig. 3. The influence of convective activity on air sampled by the WB-57 during (a) Pre-AVE and (b) CR-AVE. Map points are locations of convective systems that occurred along back trajectory paths, and are sized by the magnitude of convective influence and colored by the WB-57 flight altitude. Dark blue colors correspond to flight altitudes above the tropopause. The right panels show vertical profiles of the convective influence parameter (fraction of trajectories influenced by convection) separated by location of convective systems: Amazonia or elsewhere. Results are shown only for times when PALMS was acquiring data in tropical, cloud-free air.

temperature and the local analysis temperature profile). The overall convective influence parameter is the fraction of grid points $(0-1$, calculated as a weighted average based on grid position) intercepting a convective system (at any time in the trajectory history) for each point along the flight path. For the CR-AVE and Pre-AVE convective influence calculations, we used the NCAR/NCEP Reanalysis fields to drive a trajectory model based on (Schoeberl and Sparling, 1995). Unlike Pfister et al. (2001), where we used adiabatic trajectories (driven by GEOS-1 analyses), the parcels were allowed to change their potential temperature based on radiative heating rates calculated by Yang et al. (2009). These radiative heating rates are all-sky calculations based on CLOUDSAT and CALIPSO data. Figure 3 shows the locations of convective systems that lofted air subsequently encountered along flight paths for both Pre-AVE and CR-AVE.

As suggested by the mean circulation documented above, Pre-AVE and CR-AVE sampled very different air masses from convective systems in very different locations. During CR-AVE stronger westerlies in the upper troposphere 

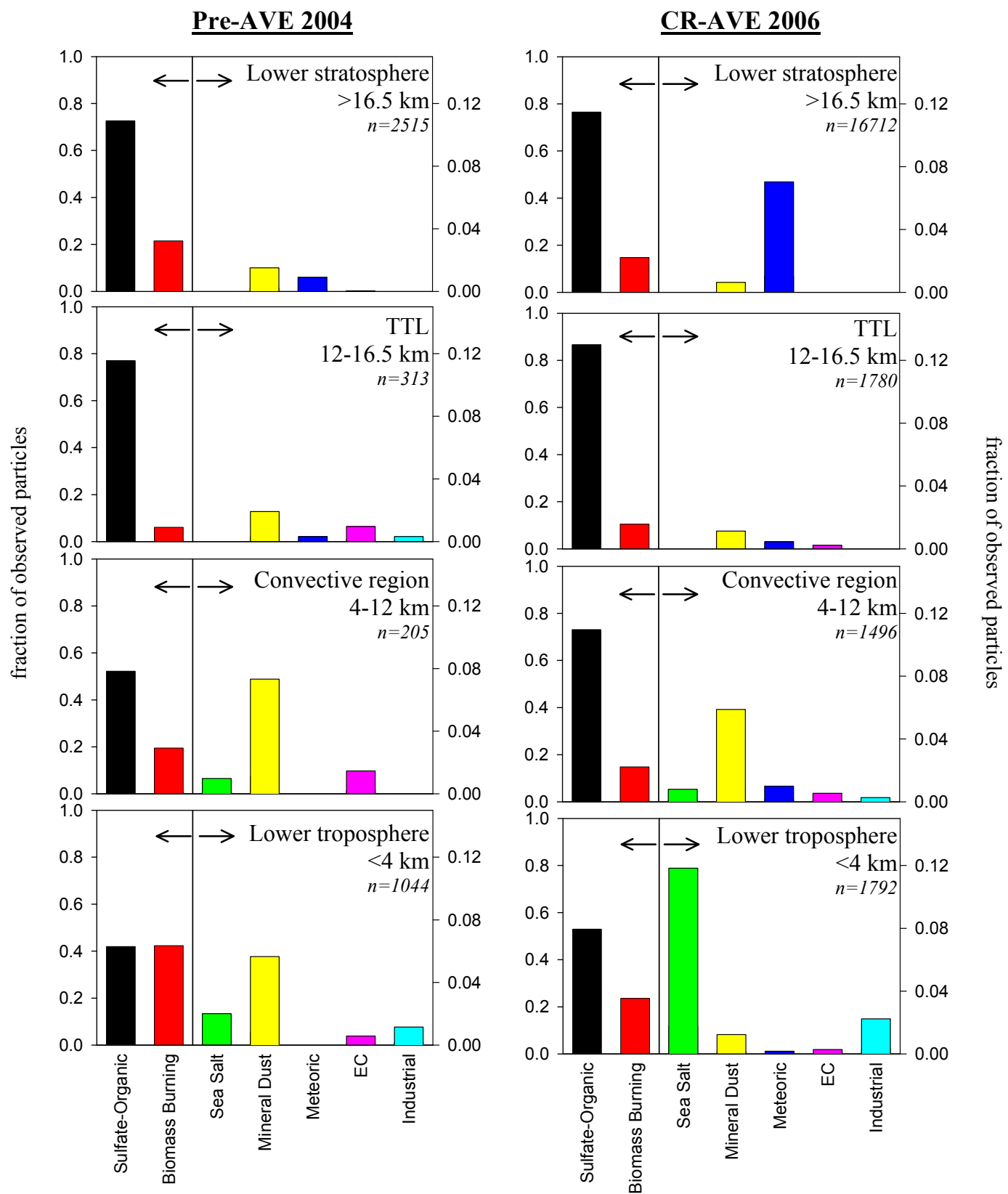

Fig. 4. Number fractions of particle types observed by PALMS at four altitude ranges. Fractions are averaged over the Pre-AVE and CR-AVE missions for cloud-free conditions south of $18^{\circ} \mathrm{N}$ latitude. Sulfate-organic mixtures and biomass burning particles are plotted against the left axis, and all other types are plotted on the right axis. Particles with ambiguous spectra or that do not fall into these classifications are not shown (typically 1-5\%). Altitude ranges are based on transitions in aerosol composition.

brought air that had been lofted over the western and central Pacific to the Costa Rica area. This convection was mostly maritime. Consistent with the nature of maritime convection, convective influence decreased rapidly above about $12 \mathrm{~km}(350 \mathrm{~K}-$ see Fig. $3 \mathrm{~b})$. For the case of CR-AVE, the abrupt decrease in convective influence clearly defines the lower boundary of the TTL. For Pre-AVE, convection influencing the sampled air was located almost exclusively over
South America. The majority of sampled air was convectively influenced up through the tropopause.

So which of the aircraft campaigns gives a more typical picture of the tropics, and in particular the TTL, during boreal winter? Figure 2 shows that upper level winds during both missions were frequently outside the 1980-2006 statistical norm. More importantly, the Pre-AVE wind direction was counter to the median. Much of the air sampled 

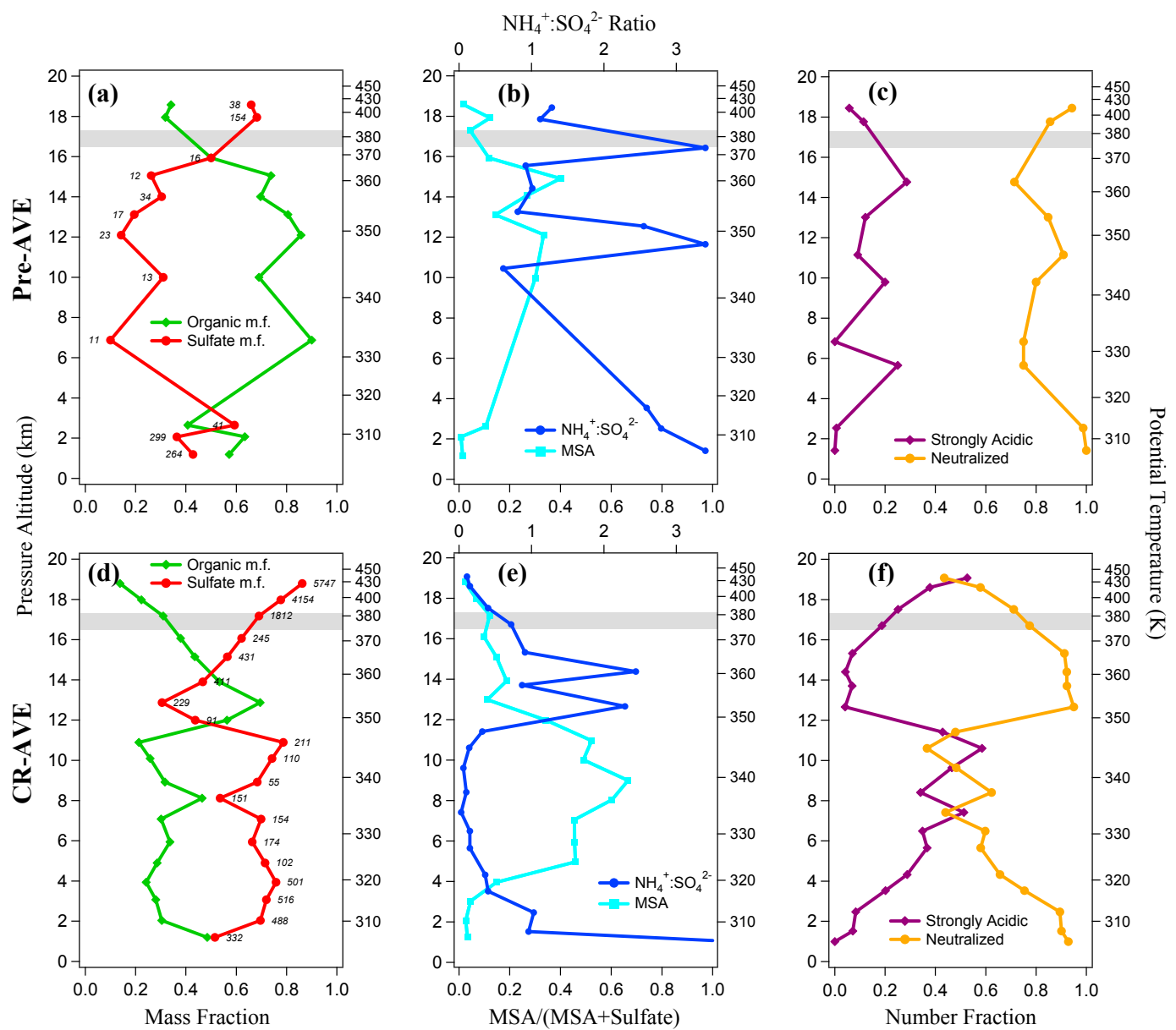

Fig. 5. Vertical profiles of sulfate-organic particle composition trends during the Pre-AVE 2004 (a-c) and CR-AVE 2006 (d-f) campaigns. (a, d) Relative mass fractions of sulfate and organic material are estimated (Murphy et al., 2006). Nitrate and other species within the particles are not considered. (b, e) Average MSA signal relative to MSA + sulfate. The acidity of sulfate-organic particles is estimated based on field calibrations (see text). Note that the fit to PILS NH $4: \mathrm{SO}_{4}^{2-}$ ratio in Fig. 1 becomes poorly constrained for ratios above 2, yielding large values that while not quantitative, nevertheless indicate a high level of neutralization. (c, $\mathrm{f}$ ) Number fraction of sulfate-organic particles containing fully neutralized sulfate $\left(\mathrm{NH}_{4}^{+}: \mathrm{SO}_{4}^{2-} \geq 2\right)$ or strongly acidic sulfate $\left(\mathrm{NH}_{4}^{+}: \mathrm{SO}_{4}^{2-}<1\right)$. Only particles sampled under cloud-free conditions and south of $18^{\circ} \mathrm{N}$ latitude are included in this analysis. Biomass burning particles are difficult to distinguish from sulfate-organic particles in negative ion mode and are inherently included in these averages. Data are binned in $1 \mathrm{~km}$ increments for bins with $>10$ suitable spectra, and data labels indicate the number of spectra. Grey shading indicates the range of the thermal tropopause. Potential temperature is calculated as $T\left(p_{0} / p\right)^{\wedge}(2 / 7)$.

during CR-AVE (even that which did not encounter convection within 14 days) came from the western Pacific. This is important because large scale trajectory models (Fueglistaler et al., 2005) show that a large part of the air in the TTL enters through the western Pacific in boreal winter. Thus, though South American convection does contribute to TTL air within the study region, globally it is less dominant than the picture painted by Pre-AVE.

\section{Results}

\subsection{Vertical profiles of composition}

Figure 4 compares the abundance of common aerosol types at four altitude ranges for the Pre-AVE and CR-AVE missions. Data from altitudes $<10 \mathrm{~km}$ were collected almost exclusively upon final descent into Costa Rica. Despite the small fraction of flight time spent here, higher particle concentrations allowed for statistically significant composition measurements. Figure 5 illustrates composition details for the internally mixed sulfate-organic particle type. Most tropical atmospheric particles $>200 \mathrm{~nm}$ were internal 
mixtures of sulfate and organic carbon, as is the case for nearly all regions of the lower atmosphere. Biomass burning particles accounted for roughly $10-20 \%$ of detected particles, which is comparable to $\sim 30 \%$ in the free troposphere over the United States outside of burning plumes (Hudson et al., 2004). Biomass burning and other continental aerosol such as mineral dust and elemental carbon were observed throughout the troposphere, indicating that these particle types were well mixed and originated from distant sources. Most sulfate-organic mixtures and biomass burning particles were $<0.6 \mu \mathrm{m}$ aerodynamic diameter (for $\rho_{p}=1 \mathrm{~g} \mathrm{~cm}^{-3}$ ). Sea salt and mineral dust aerosol were larger, $\sim 0.7$ to $>2 \mu \mathrm{m}$.

A brief description of aerosol composition from Figs. 4 and 5 for the four altitude regions follows.

\section{Lower troposphere}

Aerosol composition below $\sim 4-5 \mathrm{~km}$ was a mixture of marine and local Central American sources and is not representative of the global tropics. Sea salt accounted for up to $30 \%$ of observed particles. Metal signatures such as $\mathrm{Pb}, \mathrm{V}$, or $\mathrm{Sn}$ from industrial emissions were observed in $\sim 10 \%$ of particles. Nitrate was frequently present in sulfate-organic particles, which is typical of polluted continental aerosol. Both sea salt and particles from local Central American sources were nearly absent above $5 \mathrm{~km}$.

\section{Convective region}

At altitudes from $\sim 4-12 \mathrm{~km}$ sulfur compounds dominated the CR-AVE aerosol composition. Both sulfate and MSA (methanesulfonic acid or methanesulfonate), a highly oxidized product of dimethyl sulfide (DMS), were abundant throughout this region. $\mathrm{NH}_{4}^{+}: \mathrm{SO}_{4}^{2-}$ ratios were $\sim 0.5$ on average, and sulfate was strongly acidic (equivalent to $\mathrm{pH}<1$ ) in half the sulfate-organic particles. Average organic content was relatively low, $30-40 \%$ of the sulfate-organic mass. For the same region during Pre-AVE acidic particles were rare, and average organic mass fraction was $80 \%$.

\section{TTL}

A sharp transition occurred at $12 \mathrm{~km}$ in the CR-AVE aerosol composition. The acidic, sulfate-rich population seen below $12 \mathrm{~km}$ was virtually absent in the TTL. Carbonaceous material was at its maximum, with average organic mass fractions as high as $70 \%$. The sulfate that was present appeared mostly neutralized, with $\mathrm{NH}_{4}^{+}: \mathrm{SO}_{4}^{2-}$ ratios $>1$ and frequently 2 . The strongest transition occurred in the MSA signal, which in $1 \mathrm{~km}$ dropped by a factor of 5 relative to sulfate. The frequency of mineral dust, common at lower altitudes, also dropped by a factor of 5 above $12 \mathrm{~km}$.

\section{Stratosphere}

Another transition appeared near the tropopause, which was located at $16.5-17 \mathrm{~km}$ for both missions. Approaching the tropopause from below, organic-rich TTL particles were replaced by sulfate-rich particles formed in the stratosphere. The acidity also increased during CR-AVE, but for Pre-AVE, a neutralized sulfate population dominated throughout the lower stratosphere. These transitions occurred over several $\mathrm{km}$ altitude, due to an external mixture of tropospheric and stratospheric particle types in the vicinity of the tropopause. Organic-rich particles from the TTL constituted a significant fraction of observed particles at the maximum aircraft altitudes.

\subsection{Aerosol size}

Average aerosol size distributions from NMASS and FCAS above $7 \mathrm{~km}$ altitude are shown in Fig. 6. A well defined accumulation mode peaking at $80 \mathrm{~nm}$ occurred throughout the upper troposphere during Pre-AVE. Below the tropopause, average nuclei concentrations $(4-6 \mathrm{~nm})$ were typically below $150 \mathrm{~cm}^{-3}$. N $\mathrm{N}_{4-6 \mathrm{~nm}}$ concentrations were rarely above $500 \mathrm{~cm}^{-3}$ (Fig. 6), indicating that strong nucleation events were uncommon. An Aitken mode was not always apparent, suggesting that nuclei were often scavenged by pre-existing particles. In contrast, distinct nuclei and Aitken modes were present throughout the CR-AVE troposphere. The highest concentrations occurred below $13 \mathrm{~km}$, where $\mathrm{N}_{4-6 \mathrm{~nm}}$ concentrations were $>500 \mathrm{~cm}^{-3}$ about $50 \%$ of the flight time. Ultrafine particle concentrations decayed steadily with altitude in the TTL; average $\mathrm{N}_{4-6 \mathrm{~nm}}$ concentrations were a factor of 5 lower at the tropopause than at $13 \mathrm{~km}$, and new particle formation in the TTL was more limited. The accumulation mode was weaker and less distinct than in Pre-AVE.

Aerosol volumes in the upper troposphere were 2-5 times higher during Pre-AVE (altitude averages for $8-17 \mathrm{~km}$ : 0.10 $\left.0.60 \mu \mathrm{m}^{3} \mathrm{~cm}^{-3}\right)$ than CR-AVE $\left(0.05-0.14 \mu \mathrm{m}^{3} \mathrm{~cm}^{-3}\right)$. The CR-AVE TTL was an unusually clean region of the atmosphere. Aerosol volume experienced a minimum in the CRAVE TTL, where ambient number concentrations averaged $275 \mathrm{~cm}^{-3}$ for all sizes and $13 \mathrm{~cm}^{-3}$ for diameters $>100 \mathrm{~nm}$. An obvious size distribution transition at the tropopause was absent for CR-AVE but perhaps evident for Pre-AVE as a weakening of the accumulation mode. At $2 \mathrm{~km}$ above the thermal tropopause during both campaigns, the size distribution shifted to large accumulation mode aerosol typical of the Junge layer. Total aerosol volume in this stratospheric layer was on average a factor of 1.5 higher than in the CR-AVE TTL.

\section{Discussion}

Some tropical regions possessed unique aerosol compositions. In particular, aerosols in regions strongly influenced by 


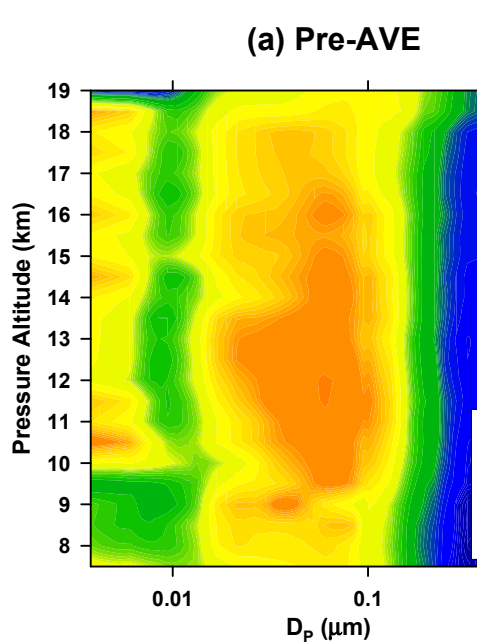

(b) CR-AVE

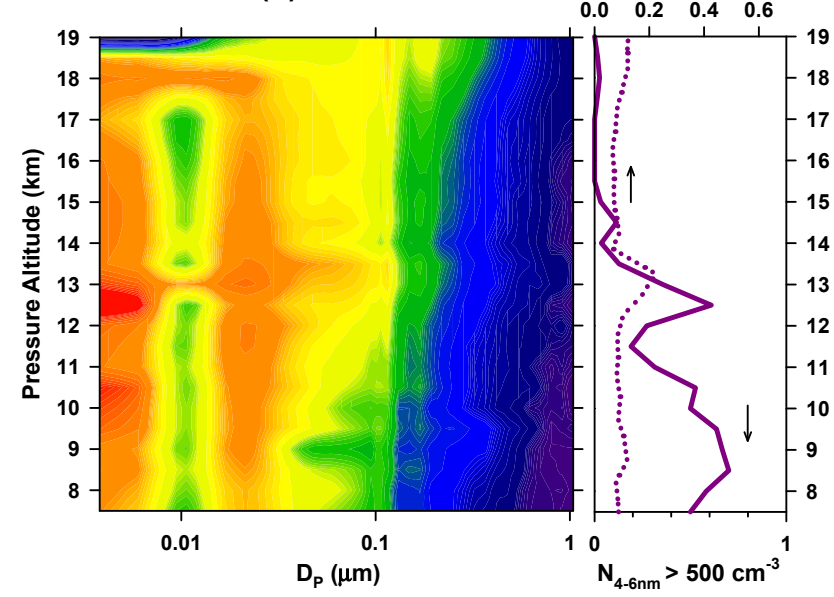

Fig. 6. Dry aerosol size distributions from NMASS and FCAS II measurements. Colors correspond to $\mathrm{dN} / \mathrm{d} \log \mathrm{D}_{p}\left(\mathrm{~cm}^{-3}\right)$ on the same logarithmic scale for both plots. Average volume for $0.1<D_{p}<1.0 \mu \mathrm{m}$ (dotted), and the fraction of measurements having 4-6 nm nuclei concentrations $>500 \mathrm{~cm}^{-3}$ (solid) are shown in the right panels. Averages are computed for cloud-free conditions and flight segments south of $18^{\circ} \mathrm{N}$.

convection showed compositions characteristic of the convective source. TTL aerosols were distinct, resembling neither particles from the stratosphere nor those of the more convectively influenced region below. Aside from one or two perturbation events, aerosol composition was consistent within a particular region during the course of measurements. In the following sections we discuss aerosol composition tracers and their relationship to convection and aerosol sources.

\subsection{Maritime convection and MSA}

\subsubsection{Sources of aerosol MSA and sulfate}

Composition and convective influence profiles in Figs. 3 and 5 suggest a relationship between MSA, acidic sulfate, and maritime convection. During CR-AVE sulfate-organic aerosol in the convective region had unusually high MSA content. The enhanced MSA region was coincident with the sulfate acidity transitions at 4 and $12 \mathrm{~km}$ (Fig. 5e), indicating a common source for MSA and sulfate that is also low in ammonia. This air was heavily influenced by convection over the Pacific from several days prior. Figure 7 a shows that the occurrence of aerosol MSA was directly dependent on the magnitude of convective influence from maritime regions. Enhanced MSA was not observed for air that had experienced Amazonian convection. The correlations between MSA, sulfate, and maritime convection indicate that the predominant sulfate precursor in this region was DMS rather than anthropogenic $\mathrm{SO}_{2}$ emissions. This is consistent with previous evidence that DMS can be the principal source of $\mathrm{SO}_{2}$ and sulfate in the remote Pacific (Davis et al., 1999) and can contribute a substantial fraction in the global tropical troposphere (Gondwe et al., 2003). In the following paragraphs we consider MSA as a tracer for maritime influence on aerosol properties.

MSA and sulfuric acid are both end products of DMS oxidation (see e.g., von Glasow and Crutzen, 2004; Zhu et al., 2006). After initial OH attack on DMS, many subsequent oxidation steps occur more quickly in cloud droplets than in the gas phase. Consequently, sulfuric acid, MSA, and many of the intermediate species are found in both the gas and aerosol phases. Using a detailed chemical reaction scheme Zhu et al. (2006) attributed $60 \%$ of MSA and $56 \%$ of sulfate production below $2.5 \mathrm{~km}$ in a convective cloud to heterogeneous oxidation. MSA production is favored over $\mathrm{SO}_{2}$ when the initial $\mathrm{OH}$ step follows the association branch, particularly when subsequent aqueous oxidation steps are considered. The relative yield of MSA therefore increases at lower temperatures due to the negative temperature dependence of the association step as well as stronger partitioning to the condensed phase (DeMore, 2006; Zhu et al., 2006). Since DMS is the only significant source of MSA, both gas phase and particulate MSA can be used as a tracer for marine influence. However, detailed source apportionment is complicated by geographically sporadic DMS emissions, the intricate oxidation scheme that involves heterogeneous processes, and long atmospheric residence times relative to transport.

The principal source of aerosols in the CR-AVE convective region below $12 \mathrm{~km}$ was probably not direct injection by convective systems. Convective cloud processing efficiently removes large, soluble particles. This was clearly evident for sea salt, which was virtually absent above $4 \mathrm{~km}$ (Fig. 4). Acidic sulfate particles large enough to be detected by PALMS should also be efficiently removed. Instead, 

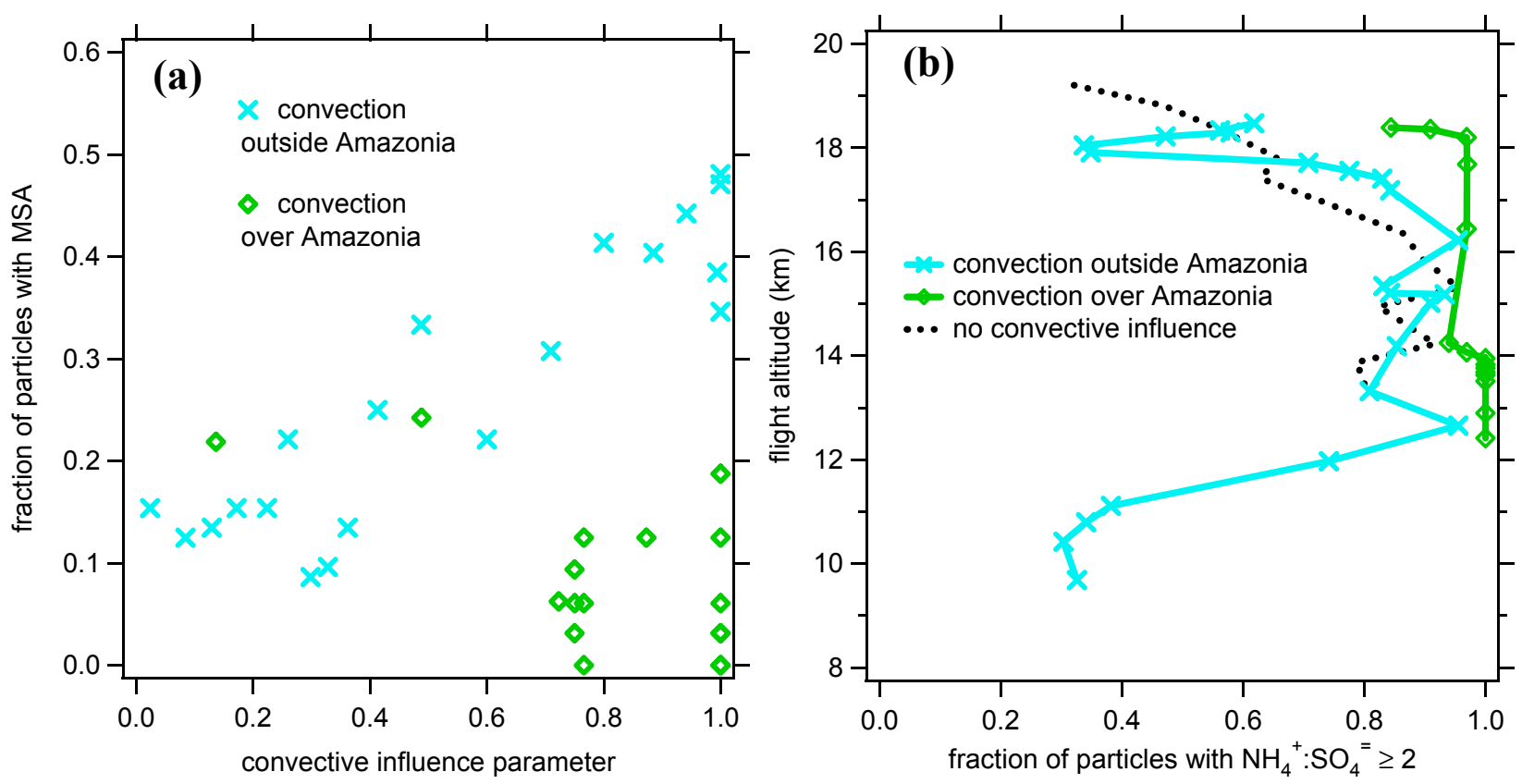

Fig. 7. Influence of convective activity on particle composition for the CR-AVE campaign. (a) Appearance of MSA for flight segments influenced by convection from two geographic sources, Amazonia or elsewhere (mostly over the Pacific). The frequency of MSA particles rises above background levels (0.2) during flight segments where non-continental convective influence is strong ( $>0.5)$. (b) Vertical profiles of aerosol sulfate neutralization for different sources of convective outflow. Air parcels impacted by Amazonian convection had a consistently higher fraction of neutralized particles, particularly evident in the lower stratosphere $(>17 \mathrm{~km})$. Points are the average of 30 (Amazonia) and 100 (elsewhere) particle spectra.

maritime convection lofted gas phase DMS from the boundary layer that then oxidized in the free troposphere to form to sulfate and MSA. The MSA-forming channel of the DMS oxidation pathway contains 3 stable intermediate species, all of which are highly soluble in water. DMS is not water soluble and therefore the most likely MSA precursor to survive convective processing. As temperatures decrease with altitude, DMS oxidation lifetime decreases to $<1$ day in the free troposphere, and the MSA-forming channel is favored above $5 \mathrm{~km}$. Subsequent oxidation inside non-precipitating clouds may leave behind MSA- and sulfate-rich aerosol. If formed in the gas phase, MSA and sulfuric acid will eventually condense onto existing aerosol. Both oxidation mechanisms can generate the low ammonium, sulfur-rich aerosol observed in cloud-free air throughout the CR-AVE convective region. The enhanced MSA levels in the CR-AVE convective region are consistent with Dibb et al. (1999) who observed high MSA:non-seasalt-sulfate ratios at $10 \mathrm{~km}$ only near the intertropical convergence zone, and speculated that the source was oxidation of convectively transported DMS.

While we are not able to identify the principal sulfur oxidation mechanism in the marine influenced troposphere, we do find evidence for both heterogeneous and gas phase processes. Mass 111 in the PALMS negative ion spectrum has been identified in the laboratory as hydroxymethanesulfonic acid (HMSA). In atmospheric particles this signal is probably HMSA, although some organic species may also contribute. HMSA is produced in cloud droplets from reaction of dissolved $\mathrm{SO}_{2}$ and formaldehyde, and its presence in clear air aerosol indicates previous cloud processing (Munger et al., 1986; Whiteaker and Prather, 2003; S. H. Lee et al., 2003a). HMSA was detected most frequently in the CR-AVE convective region and was correlated with MSA. HMSA and MSA are not known to directly interconvert, and instead their presence in the same particles suggests that MSA was formed via an aqueous pathway. The aerosol below $12 \mathrm{~km}$ are larger than typical sulfate-organic aerosol, which is also consistent with recent cloud processing. A significant fraction of the population (25\% compared to $5 \%$ for the TTL and stratosphere) had geometric diameters larger than $0.6 \mu \mathrm{m}$ (assuming $\rho_{p}=1.7 \mathrm{~g} \mathrm{~cm}^{-3}$ ), and the tail of the distribution extended beyond $1 \mu \mathrm{m}$. Furthermore, HMSA was found preferentially in larger particles: $50 \%$ of those $>0.45 \mu \mathrm{m}$ contained detectable HMSA, but only $10 \%$ of $0.25 \mu \mathrm{m}$ particles contained HMSA.

Sulfate was not produced exclusively within cloud droplets. Although there were no direct measurements of gas phase sulfur species onboard the aircraft, widespread new particle formation in the CR-AVE convective outflow region implies the production of gas phase sulfuric acid from 
DMS. New particle formation in this region is consistent with a sulfuric acid nucleation mechanism (Lovejoy et al., 2004; S. H. Lee et al., 2003b). Production of $4 \mathrm{~nm}$ particles here would require gas phase sulfuric acid concentrations in excess of $\sim 2 \times 10^{6} \mathrm{~cm}^{-3}$ (Lovejoy et al., 2004; Kazil et al., 2006).

In contrast to CR-AVE, sulfate-organic particles in the PreAVE troposphere showed limited influence of marine material in the form of MSA (Fig. 5b). In both 2004 and 2006 MSA in the TTL was near or slightly higher than background levels $(\sim 0.2)$ typical of continental air over North America. The convective influence analysis suggests a limited maritime source within the previous 14 days. MSA in this and other background regions may be explained by its long atmospheric lifetime in particulate form, similar to sulfate. Particulate MSA is likely to be found far from oceanic sources, and indeed, detectable amounts were found at the highest stratospheric altitudes.

\subsubsection{Source regions and mechanisms for $4-12 \mathrm{~km}$ aerosols}

It is important to note that while maritime influence was high below $12 \mathrm{~km}$ during CR-AVE, aerosols were externally mixed and represented a variety of sources. Organic-rich particles with neutralized sulfate still comprised a large fraction of observable aerosol (Fig. 5f). Biomass burning particles and mineral dust were also common. These continental particle types have been observed in a variety of mid-latitude and tropical regions, and they are long-lived and often well mixed in the troposphere. They are also less efficient CCN than sulfate and may have been effectively lofted by convective systems over Indonesia (Fig. 3b).

The sulfate-organic aerosol population was an external mixture of two broadly defined categories: those with and without a strong acidic sulfate signature (Fig. 5f). Particles without an acidic signature were highly organic, usually contained nitrogen, and resembled sulfate-organic mixtures found in continental regions. These particles were ubiquitous throughout the troposphere. Acidic particles were only common in the stratosphere and from 4-12 km during CRAVE. Spectra of acidic particles consistently showed little or no organic material. This is not surprising in the stratosphere since those particles were formed in a low organic environment. However, it is unusual to see such low organic signatures in the free troposphere. If such an anti-correlation between organic content and sulfate acidity were a general feature of tropospheric aerosols, there may be important implications for secondary aerosol formation and aerosol-cloud interactions. We therefore examine four possibilities to explain this observation: 1) In acidic aerosol the ionization efficiency of organic material is reduced relative to sulfate in negative spectra. Sulfate-organic mass fraction calibrations (Murphy et al., 2006) were performed in polluted conditions where particles were predominantly neutralized. However, a reduction in organic peak intensities was also observed in positive spectra, where organic ions usually dominate the ion current. Also, laboratory generated particles showed consistent organic signals for dicarboxylic acid-sulfate mixtures for $\mathrm{NH}_{4}^{+}: \mathrm{SO}_{4}^{2-}=1-2$. This evidence does not support composition-dependent ionization efficiency as the primary cause, although more detailed studies are required. 2) Soluble organic material in sufficient quantities acts as a buffer for sulfate ions in solution. However, since most primary and secondary organic species are usually generated in an acidic form incapable of buffering, there are no obvious organic candidates that might alter sulfate ion equilibria to a measurable extent. 3) Secondary organic material accumulates more effectively onto aerosols when sulfate is neutralized. Recent laboratory studies suggest a possible enhancement of SOA production when ammonium is present (Noziere et al., 2009). 4) High concentrations of gas phase $\mathrm{SO}_{2}$ or sulfuric acid partitioned to existing and freshly formed particles, both increasing their acidity and decreasing the relative organic mass fraction. This is the most likely cause for low relative organic content of acidic particles in the CR-AVE dataset. Precipitation scavenging that removes a large fraction of the particles can create a clean template for the growth of relatively pure sulfate particles (Brock et al., 2004). This sulfate accumulation scenario has further implications regarding tropospheric particle sources. In this case the acidic, sulfate-rich and the sulfate-poor particles observed in this region must be generated from different sources. In support of this idea, positive ion sulfate signatures on biomass burning particles did not follow the vertical profile of sulfate content in Fig. 5d. This indicates that not all particles in this region acquired sulfate by the same mechanism in the same region, e.g., condensation of gas phase sulfuric acid generated by DMS.

Overall, the aerosol composition below the TTL during CR-AVE was consistent with efficient removal of marine boundary layer aerosol, convective transport of DMS, followed by both gas phase and heterogeneous oxidation rather than direct lofting of aerosols. The concurrence of sulfaterich/MSA particles with neutralized, organic-rich particles is evidence that sulfate-organic aerosol represented multiple sources. The abrupt drop in particulate MSA and acidic sulfate aerosol above $12 \mathrm{~km}$ suggests that direct injection of marine boundary layer material is not a principal source of aerosols to the TTL.

\subsection{Amazon convection and organic material}

\subsubsection{Origins of organic-rich aerosol}

Convection over Amazonia and agricultural areas of South America during Pre-AVE resulted in enhanced levels of organic-rich, low acidity aerosol throughout the troposphere. These organic-rich particles detected by PALMS were at the tail of the distinct accumulation mode peaking at $80 \mathrm{~nm}$ (Fig. 6) that constituted nearly all the aerosol mass. 
Tropospheric aerosol composition was remarkably consistent up through $\sim 16 \mathrm{~km}$ where the convective influence began to drop. Marine convective input was minimal and did not inject large amounts of DMS or other sulfur species to the region. Sulfate signals on mineral dust were a factor of $\sim 7$ lower in the Pre-AVE troposphere than during CR-AVE. This a consequence of low sulfur emissions coincident with South American dust and insufficient time to accumulate entrained free tropospheric sulfate. The high aerosol loadings and low sulfuric acid precursor material from Amazonia suppressed new particle formation in the upper troposphere.

Pre-AVE occurred during the Amazonian wet season when biomass burning was at a minimum. Biomass burning particles in the free troposphere were at or below typical background levels and did not contribute significantly to the aerosol organic mass. Spectra of biomass burning particles typically show sulfate accumulation within several days of emission (Hudson et al., 2004). Sulfate signal levels on biomass burning particles in the Pre-AVE and CR-AVE troposphere were similar to those in mid-latitudes outside of strong burning plumes, indicating that they were generated from distant fires. Since biomass burning influence was low during Pre-AVE, the elevated organic aerosol mass must then be primary or secondary biogenic material from Amazonia.

Ground level aerosols in the Amazonian Basin during the wet season are largely biogenic. From bulk composition measurements in the remote Amazon, Graham et al. (2003a) found that $70 \%$ of $<2 \mu \mathrm{m}$ particle mass was organic matter predominantly from biogenic material. Water-soluble organic matter can constitute more than half of the submicron aerosol mass (Fuzzi et al., 2007). Oxidized organics have also been identified in Amazonian aerosol. Carboxylic acids comprise $\sim 10 \%$ identifiable organic matter from biogenic aerosol during the wet season (Falkovich et al., 2005). Claeys et al. (2004) observed polyols in biogenic Amazonian aerosol. In these studies a significant fraction of the unidentified organic mass was thought to be high molecular weight polyacid compounds.

\subsubsection{Oxidized organics and biogenic SOA}

Oxidized organic signals observed in the continentally influenced Pre-AVE troposphere and stratosphere were 5 times higher than during CR-AVE and were the most intense ever measured by PALMS on a regional scale. PALMS negative ion spectra have several signatures that represent oxidized organic material, including $\mathrm{C}_{\mathrm{x}} \mathrm{H}_{\mathrm{y}} \mathrm{O}_{2}^{-}(\mathrm{m} / \mathrm{z}, 45,59,73,87)$ and $\mathrm{C}_{\mathrm{x}} \mathrm{H}_{\mathrm{y}} \mathrm{O}_{4}^{-}(89,103,117,131,145)$. These ions are produced with much lower efficiencies than general carbon indicators (e.g., $\mathrm{C}_{2}^{-}$and $\mathrm{C}_{2} \mathrm{H}^{-}$) and are not always observed. The $\mathrm{C}_{\mathrm{x}} \mathrm{H}_{\mathrm{y}} \mathrm{O}_{2}^{-}$peaks are the more intense series and are general markers of oxidation, which, as a fraction of total organic signal, may be a qualitative measure of water soluble organic carbon (WSOC) content. In laboratory studies the $\mathrm{C}_{\mathrm{x}} \mathrm{H}_{\mathrm{y}} \mathrm{O}_{4}^{-}$ series was produced by dicarboxylic acids such as oxalic and

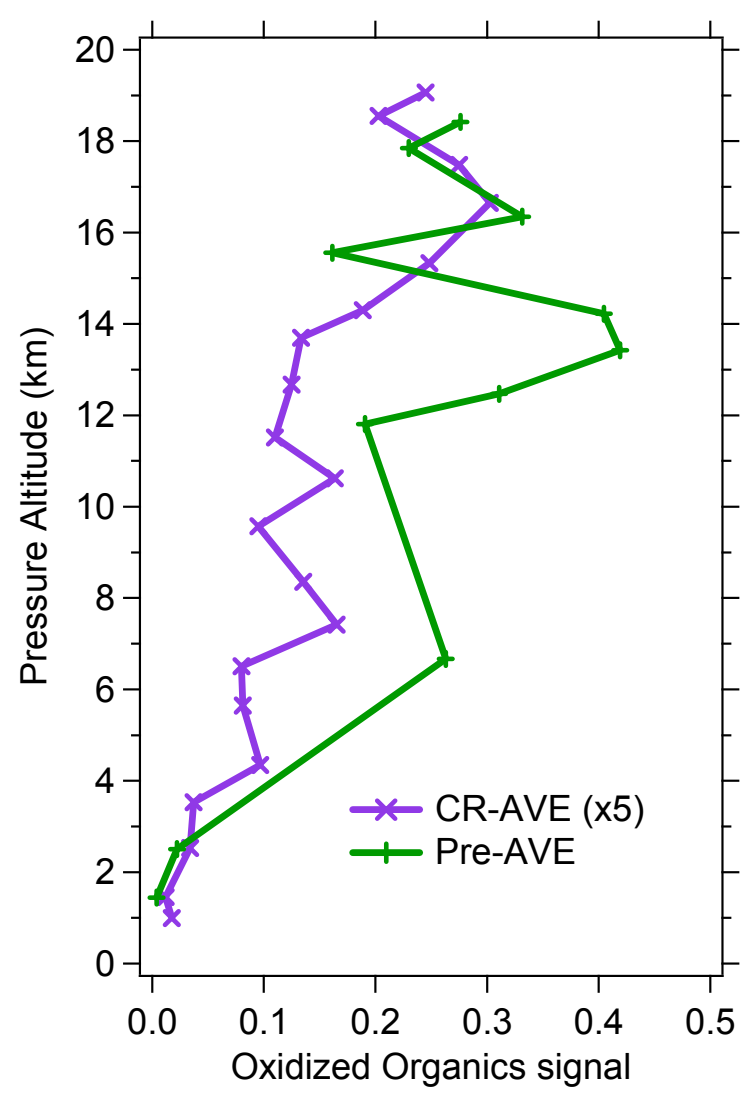

Fig. 8. Relative oxidation level of organic material in sulfateorganic particles. Oxidized organics signal is the sum of $\mathrm{C}_{\mathrm{x}} \mathrm{H}_{\mathrm{y}} \mathrm{O}_{2}^{-}$ and $\mathrm{C}_{\mathrm{x}} \mathrm{H}_{\mathrm{y}} \mathrm{O}_{4}^{-}$peaks relative to total organic signal. CR-AVE signals are scaled by $\times 5$. An event on 30 January 2006 (see text) was excluded. Points are $1 \mathrm{~km}$ averages when there were at least 5 suitable spectra.

succinic acids, but they may also be fragments from other polyacids or larger oxidized compounds. Figure 8 compares oxidized organic levels for the two missions. Low vertical resolution limits interpretation of the lower and middle troposphere, but the most highly oxidized material resided in the TTL.

The unusually high levels of dicarboxylate and other oxidation signatures in the Pre-AVE troposphere point to a unique source or mechanism. Based on aerosol size and composition results, there was no significant contribution from convective injection of primary biological aerosols (pollen, leaf material, fungal spores). Phosphate was very rare, and there was no enhancement of coarse mode organic aerosol, where most primary biogenic particles reside (Graham et al., 2003b; Fuzzi et al., 2007). Instead, our data are consistent with secondary organic aerosol (SOA) formed from volatile organic compounds (VOCs).

Biogenic material in Amazonian submicrometer aerosol during the wet season in mostly secondary (Graham et al., 2003b; Fuzzi et al., 2007). Laboratory studies confirm that 


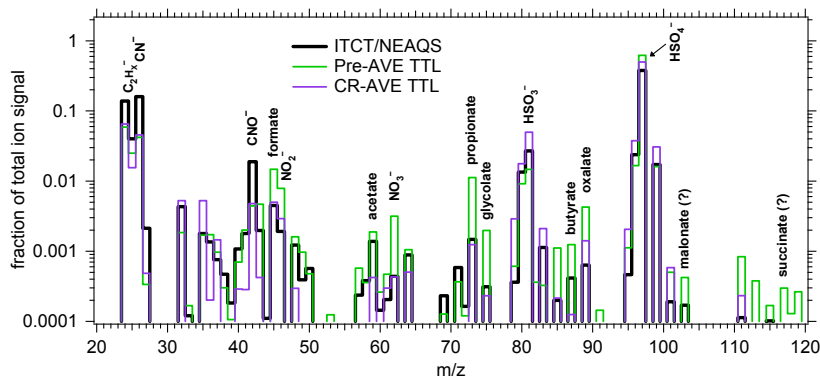

Fig. 9. Comparison of average negative ion spectra of sulfateorganic particles for air impacted by Amazonian convection (PreAVE TTL), aged air with little convective influence from the previous 14 days (CR-AVE TTL), and a polluted continental case (ITCT/NEAQS 2004, 3-7 km). Prominent oxidized organic species are labeled. Many unlabeled minor peaks are also due to organic species. For comparison, in the marine-influenced CR-AVE troposphere at $<12 \mathrm{~km}$ (not shown), all labeled oxidized organic signals other than formate were $\leq 0.0001$.

biogenic SOA can be generated in low- $\mathrm{NO}_{\mathrm{x}}$ environments from isoprene and monoterpene precursors (Kavouras and Stephanou, 2002; Kroll et al., 2006; Ng et al., 2007), and this process has been observed specifically in the Amazonian forest (Lim et al., 2005). It is difficult to determine whether SOA produced in the Amazonian boundary layer was lifted to the upper troposphere or if gas phase precursors were lifted and then converted to SOA. Probably both mechanisms contributed. On the one hand, aerosols of the Pre-AVE troposphere and tropopause region showed organic mass fractions, oxidation signatures, and sulfate neutralization that are broadly consistent with the composition of wet season Amazonian aerosol. Also, free tropospheric mineral dust was slightly enhanced during Pre-AVE and showed little atmospheric aging, which supports some contribution from a direct injection mechanism. On the other hand, low oxidant levels in the canopy often limit terpene oxidation (Kesselmeier et al., 2002) and therefore SOA conversion. SOA yields may be enhanced if biogenic VOCs are injected into the upper troposphere where oxidant levels are higher. Amazonian material spent 2-4 days in the upper troposphere prior to aircraft sampling. Gas phase isoprene or monoterpenes would undergo significant conversion in this time. In addition, dicarboxylic acids are efficiently generated from aqueous reactions of dissolved VOCs within tropospheric cloud droplets, and are subsequently retained in aerosol upon evaporation (Ervens et al., 2004; Sorooshian et al., 2007a, b). Oxidation signatures and particle aging within the TTL are discussed further in Sect. 5.3.2.

\subsection{TTL and the tropopause region}

In this section we describe aerosol compositional properties of the TTL region and discuss likely sources and mecha- nisms. Because the Pre-AVE atmosphere was heavily influenced by recent continental convection, we focus instead on CR-AVE under the assumption that these data may be more representative of the global tropical upper troposphere.

\subsubsection{Maximum organic mass fraction}

Aerosol in the tropical tropopause layer must have either been transported through the lower troposphere via convection or gradual ascent, formed at high altitude from precursor gases, or descended from the stratosphere. Maritime convection lofted sulfate precursor material directly to altitudes $<13 \mathrm{~km}$ during CR-AVE, but aerosol in the TTL was generated by a different (or subsequent) mechanism. The maximum organic mass fraction occurred at $13 \mathrm{~km}$ at the bottom of the TTL, where sulfate-organic particles were on average $70 \%$ organic material. Average organic content decayed steadily with altitude through the TTL and stratosphere. The organic signal decay is not entirely explained by an increasing fraction of externally mixed sulfate-rich stratospheric particles; their abundance is very low below $15 \mathrm{~km}$. Instead, the decline of relative organic content was due to composition changes within TTL particles, either loss of organic material or accumulation of sulfate. Sulfate signals on mineral dust increased by a factor of 4 from 15 to $17 \mathrm{~km}$, indicating that to some extent sulfuric acid uptake occurred below the tropopause.

Convection from Amazonia was not as widespread throughout the CR-AVE TTL as during Pre-AVE. However, Fig. $3 \mathrm{~b}$ does indicate a strong Amazonian influence at $13 \mathrm{~km}$ that was responsible for the maximum organic mass fraction at that level. Like Pre-AVE, continental convection penetrates into the TTL and affects TTL aerosol composition. Spectra for sulfate-organic aerosols throughout the entire CR-AVE TTL strongly resembled those found in polluted regions of North America in terms of organic content, oxidation, sulfate neutralization, and nitrate (Fig. 9). Although not definitive, this chemical similarity suggests that continental material may disproportionately contribute to TTL aerosol mass even outside of regions directly impacted by deep convection.

During TTL flight segments without recent continental input, organic mass fractions were still higher on average (0.47) than at lower altitudes (0.29). In addition to direct injection of continental material, there are several other possibilities that may contribute to the abundance of organicrich particles in the TTL: 1) A sub-population of organicrich aerosols in the marine boundary layer preferentially survives convection and pools near the level of cloud outflow. Although it is clear from the sea salt profile that soluble marine boundary layer aerosols are not efficiently transported to the TTL, Ekman et al. (2006) calculated that insoluble, non-hygroscopic particles (black carbon in that study) are preferentially lofted by convective systems, leading to cloud top enhancements. This mechanism would provide a supply 
of organic particles at the base of the TTL. 2) Organic-rich particles are poor ice nuclei and are not as easily removed from the TTL. Recent field and laboratory studies indicate that sufficient amounts of some organic species reduce that ability of aerosols to freeze (Cziczo et al., 2004a; Murray, 2008; Zobrist et al., 2008). Mineral dust particles, which act as efficient ice nuclei, were significantly reduced above $12 \mathrm{~km}$, supporting the idea of a selective removal mechanism. 3) Long residence times and low temperatures allowed for accumulation of organic material onto existing aerosols. In the mid-latitudes, meteoric particles formed in the stratosphere accumulated organic material as they fell below the tropopause (Murphy et al., 2007a). This effect was also observed during CR-AVE even above the tropopause, confirming that an organic accumulation mechanism is active in the tropical upper troposphere and lower stratosphere. However, the amount of material that partitions via this mechanism is difficult to estimate and may account for only a small fraction of upper tropospheric aerosol organic mass. We explore this organic accumulation mechanism further in the following section.

\subsubsection{Particle aging}

During CR-AVE aerosol organic material in the TTL was more oxidized than at lower altitudes (Fig. 8). From the organic mass fraction maximum at $13 \mathrm{~km}$ up to the tropopause, total organic content decreased and the average oxidation signature increased by more than a factor of 2 . Signal levels for particles of known composition generated in the laboratory suggest that highly oxidized organic species (e.g., short chain dicarboxylic acids) must comprise $\gg 1 \%$ of aerosol mass in the CR-AVE TTL. With limited recent continental convective influence during CR-AVE, the oxidized organic material may be a signature of particle aging, resulting from either oxidation of organics at the particle surface by $\mathrm{OH}$ and $\mathrm{O}_{3}$ (Rudich, 2003) or oxidation of well mixed gas phase species that then partitioned to aerosols at the low temperatures of the TTL. Sonde and aircraft data show increases in ozone and HOx in the TTL (Folkins et al., 1999; Wennberg et al., 1998), consistent with increasing oxidative capacity below the tropopause. Back trajectories and convective influence for flight segments near the CR-AVE tropopause generally indicated little influence from the lower atmosphere, so that most VOCs and aerosols were not further perturbed after entering the TTL.

We examine the possibility of organic material accumulation via oxidation of gas phase organic compounds for background tropospheric conditions. The average ascent rate in the CR-AVE TTL was determined by Park et al. (2007) to be $0.13 \mathrm{~km} \mathrm{day}^{-1}$, giving overall TTL residence times of around 1 month. To produce the average CR-AVE TTL aerosol organic mass in 1 month, the required production rate of condensable organic species is $\sim 100$ molec $\mathrm{cm}^{-3} \mathrm{~s}^{-1}$. Assuming a hydroxyl radical concen- tration of $1-2 \times 10^{6} \mathrm{~cm}^{-3}$ (Wennberg et al., 1998) and rate constant $k_{\mathrm{OH}}=1 \times 10^{-13} \mathrm{~cm}^{3}$, this corresponds to a gas phase reactant with a steady state mixing ratio of $300 \mathrm{pptv}$. This rate constant is appropriate for a wide variety of gas phase organics species, in particular, aldehydes, ketones, peroxides, and unsaturated hydrocarbons (DeMore, 2006; Atkinson et al., 2006). In other studies, the most abundant nonmethane hydrocarbons (NMHCs) in the remote upper troposphere $(<12 \mathrm{~km})$ were ethane, ethyne, propane, and short chain oxygenated species: methanol, acetone, acetaldehyde, and methyl peroxide (Blake et al., 2003a; Singh et al., 2004). Total NMHC levels were 1-5 ppbv. However, many of these species do not yield known condensable products. One exception is ethyne, a precursor to glyoxal. Cloud processing of glyoxal efficiently produces low volatility products (glyoxylic and oxalic acids) that contribute to aerosol mass, but this mechanism requires a liquid environment not available in the TTL. In laboratory studies Iraci et al. (2002) and Michelsen et al. (2006) have shown that many short chain oxygenated organic species do not strongly partition to sulfuric acid aerosol even at upper tropospheric temperatures, and further oxidation in the TTL would not yield condensable products. One possibility is that oxygenated VOC uptake is enhanced by excess ammonium present in the neutralized sulfate aerosol of the TTL. Noziere et al. (2009) recently discovered an ammonium ion catalysis mechanism that may promote SOA production preferentially in neutralized sulfate aerosols. Overall, the increasing organic oxidation signatures are consistent with particle aging in the TTL, but the accumulation mechanism and the precursor species are uncertain.

\subsubsection{Sulfate neutralization}

Acidity signatures in the CR-AVE TTL were much lower than in the convective region and suggest that ammonium sulfate, $\left(\mathrm{NH}_{4}\right)_{2} \mathrm{SO}_{4}$, and letovicite, $\left(\mathrm{NH}_{4}\right)_{3} \mathrm{H}\left(\mathrm{SO}_{4}\right)_{2}$, were the most common forms of sulfate. At $12 \mathrm{~km}$ the fractional population of acidic sulfate-organic particles dropped from $50 \%$ to 5\% and only began to increase upon approaching the tropopause (Fig. 5f). This acidity transition again highlights the separation of aerosol properties between the TTL and the convective region below. As discussed in Sect. 5.1.1, the similarly abrupt drop in aerosol MSA content and maritime convective influence indicate that direct injection is not a major source of TTL aerosol material outside of continental regions. Furthermore, the sharp decrease in the acidic aerosol population suggests that even non-convective transport across the lower TTL boundary may be inefficient. Particles transported into the lower TTL may accumulate ammonia and organic species such that their composition no longer resembles the convective region aerosol. However, unless these processes alter aerosol chemical composition on a timescale faster than transport from 12 to $13 \mathrm{~km}$, one would instead expect a more gradual transition similar to trace gas species (e.g., Park et al., 2007). Also, sulfate-organic 


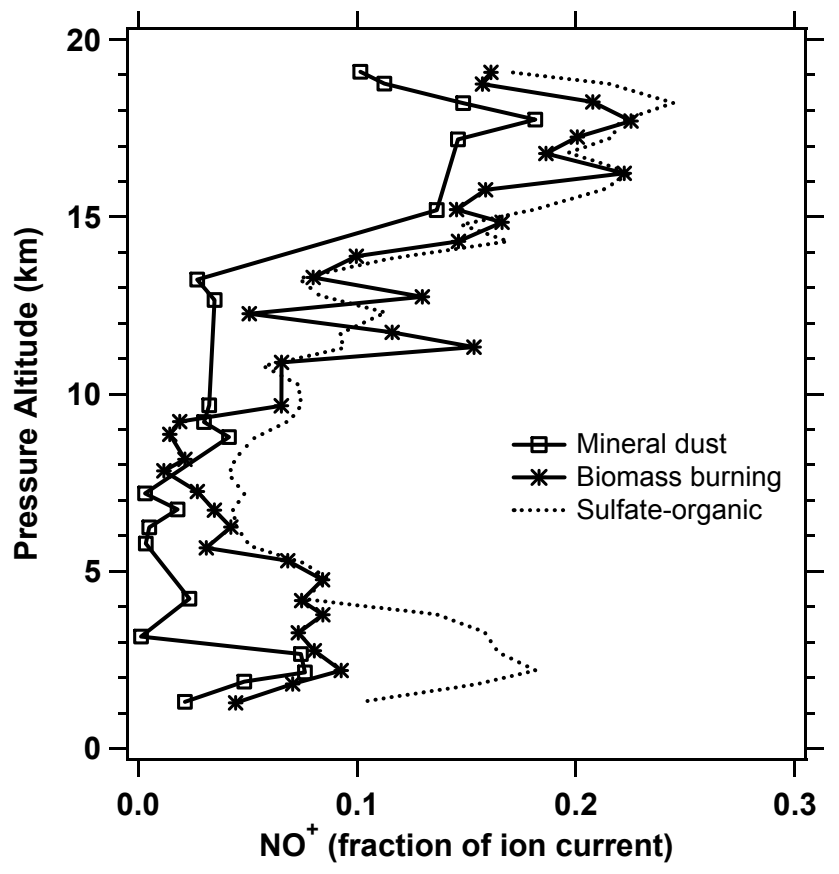

Fig. 10. Total nitrogen signal in several particle types for CR-AVE during cloud-free conditions. Ammonium, inorganic nitrate, and organic nitrate all contribute to the $\mathrm{NO}^{+}$signal. Points are averages for $0.5 \mathrm{~km}$ bins that contained at least 5 suitable spectra.

particles in the lower TTL are smaller than those below, which does not support the idea of substantial composition changes from accumulation.

Figure $7 \mathrm{~b}$ shows that sulfate neutralization in the tropopause region was directly related to continental convection. For most periods during CR-AVE, average sulfate acidity increased steadily above the tropopause, but stratospheric air influenced by Amazonian convection contained more neutralized sulfate particles. Similarly, Amazonian convection exerted a strong influence on air throughout the Pre-AVE troposphere into the lower stratosphere, with estimates of $\mathrm{NH}_{4}^{+}: \mathrm{SO}_{4}^{2-}$ ratio frequently $\geq 2$ even above the tropical tropopause (Fig. 5b, c). Ground level studies in Amazonia show that sulfate in wet season aerosol is on average fully neutralized, with ammonium being the most abundant cation (Fuzzi et al., 2007). These results demonstrate that Amazonian convection can be a defining influence on aerosol composition even 1-2 km above the tropical tropopause.

\subsubsection{Sources of nitrogen}

TTL particles were rich in nitrogen. In positive spectra $\mathrm{NO}^{+}$ is a sensitive but unspecific measure of total nitrogen content that is due to a combination of nitrate, ammonium, amines, and organic nitrate. To investigate the source and speciation of nitrogen, we plot $\mathrm{NO}^{+}$altitude profiles for several particle types (Fig. 10). The fact that altitude profiles for different particle types show similar features throughout the

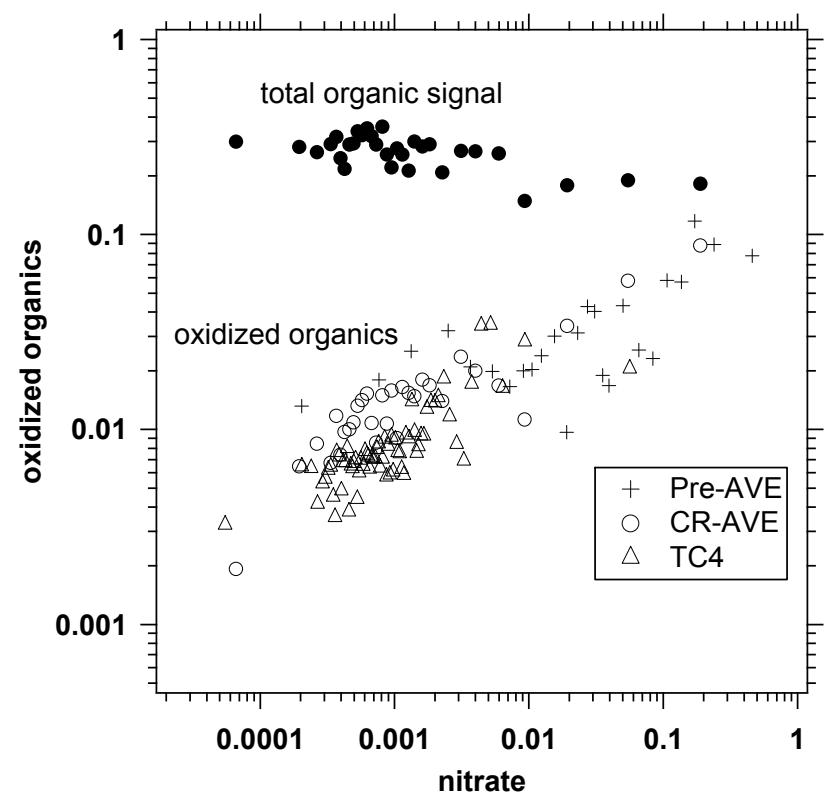

Fig. 11. Correlation between fractional ion current for nitrate $\left(\mathrm{NO}_{2}^{-}+\mathrm{NO}_{3}^{-}\right.$) and oxidized organics (sum of $\mathrm{C}_{\mathrm{x}} \mathrm{H}_{\mathrm{y}} \mathrm{O}_{2}^{-}$) in individual sulfate-organic aerosol for tropical missions (open points). Total organic signal (solid points) shows no correlation. Points are the average of 15-25 particle spectra.

TTL and below suggests a common nitrogen source mechanism. One explanation is that particles with nitrogen originated from similar regions. If the particles in the TTL were originally generated, for example, in a polluted continental boundary layer, they might exhibit similarly enhanced $\mathrm{NO}^{+}$ signatures. Alternately, aerosol nitrogen may be the result of an accumulation mechanism that affects all particle types, e.g., gas phase condensation.

Gas phase ammonia will condense onto aerosol particles containing acidic sulfate. Although it is difficult to distinguish a clear $\mathrm{NH}_{4}^{+}$signature in PALMS spectra, $\mathrm{NO}^{+}$ for sulfate-organic particles, as well as candidate $\mathrm{NH}_{4}^{+}$ signatures (Sect. 2), generally correlated with the derived $\mathrm{NH}_{4}^{+}: \mathrm{SO}_{4}^{2-}$ ratio below the tropopause. The data are consistent with ammonium (or amines) acting as the neutralizing agent in the TTL. However, the source of aerosol ammonium remains uncertain. There are no direct gas phase ammonia measurements in the upper troposphere, but concentrations are thought to be $\sim$ tens of pptv with maxima in the tropics (Dentener and Crutzen, 1994; Burgess et al., 2006). This is insufficient to neutralize the aerosol mass inferred from the size distributions. Overall an ammonia accumulation mechanism cannot be verified with these measurements. However, source apportionment of neutralized sulfate indicates that continental convection of either aerosol ammonium or gas phase ammonia almost certainly contributed to enhanced nitrogen content of the TTL. 
Nitric acid readily condenses onto mineral dust as well as fully neutralized sulfate-organic or biomass burning particles at most tropospheric temperatures. In this way, the $\mathrm{NO}^{+}$signal is sensitive to particle neutralization from the likely neutralizing agent, ammonium, and the subsequent accumulation of nitrate. At temperatures below about $197 \mathrm{~K}$, gas phase nitric acid condenses reversibly onto acidic sulfate aerosols. In Fig. 10 the $\mathrm{NO}^{+}$maximum for sulfate-organic particles at the tropopause is due to this reversible condensation of nitric acid. Even at higher temperatures (below $15.5 \mathrm{~km})$ in the TTL, a large fraction of sulfate-organic particles are neutralized, and nitrogen accumulation by $\mathrm{HNO}_{3}$ uptake partly explains the similar altitude profiles of mineral dust and sulfate-organic aerosol. Gas phase nitric acid is generated in the upper troposphere by reaction of $\mathrm{NO}_{2}$ with $\mathrm{OH}$. Continental convective systems provide a $\mathrm{NO}_{\mathrm{x}}$ source to the upper troposphere by lofting boundary layer pollution and also through lightning generation (Tie et al., 2002). Deep convection into the TTL such as during Pre-AVE may therefore enhance aerosol nitrogen content.

In negative ion spectra low intensity nitrate signals $\left(\mathrm{NO}_{2}^{-}\right.$ and $\mathrm{NO}_{3}^{-}$) were occasionally observed. Nitrate signatures were closely correlated with oxidized organics in individual particles (Fig. 11). This correlation could arise if the oxidized organic material was directly associated with fully neutralized sulfate particles that could also accumulate $\mathrm{HNO}_{3}$. The sulfate in most of these nitrogen-rich particles from both missions appeared fully neutralized. However, several spectra with nitrate also indicated acidic sulfate, and all these particles contained carbonyl peaks as well. In such particles, some aerosol nitrate may have been present as organic nitrate. In the Amazonian Basin, Mace et al. (2003) found that organic nitrogen in wet season aerosol accounted for $45 \%$ of the total nitrogen content. Gas phase alkyl nitrates and peroxy nitrates have long enough lifetimes in the free troposphere to be transported great distances from sources, and these species can partition to aerosol particles. They are typically found in the remote atmosphere at $\sim 10-100$ 's of pptv (Blake et al., 2003b; Singh et al., 2004), and at these concentrations organic nitrate partitioning could add several percent to the particle mass over a few weeks. Alternately, organic species may react with the nitrate radical ( $\mathrm{Ng}$ et al., 2008) or inorganic nitrate (Iraci et al., 2007) to generate secondary aerosol material.

One event during CR-AVE was characterized by unusually high nitrate and oxidized organic levels. On 30 January from 16:30-17:10 UTC at $200 \mathrm{~K}$, average nitrate signals in the upper troposphere were 1000 times higher than the mission average. Air had been in the upper troposphere for $>8$ days, crossed the Pacific from eastern Asia and Indonesia, and experienced limited recent convection. Gas phase tracers suggest slightly higher-than-average continental influence for that altitude. Biomass burning particle abundance did not indicate the presence of a fire plume. The origin of the unusual aerosol composition is unknown. However, this case illustrates that nitrate- and oxidized organic-rich particles in the free troposphere are not confined only to regions that had experienced recent uplift from the continental boundary layer.

\subsection{Transport across the tropopause}

In previous studies of the mid-latitude and sub-tropical lower stratosphere, PALMS identified two broad populations of sulfate-organic aerosol particles: those of stratospheric origin and those that had crossed the tropopause (Murphy et al., 2007a). Stratospheric particles contained sulfuric acid with little organic material. Tropospheric particles were organicand nitrogen-rich and had low acidity markers. These two broad aerosol populations remained distinct in the stratosphere even after months of residence time. Redistribution of semi-volatile organics from tropospheric to stratospheric particles was limited.

Similarly, the tropical tropopause region contained a mixture of stratospheric and tropospheric aerosol that extended well above and below the cold point. Organic-rich tropospheric particles were common in the lower stratosphere for both tropical missions. For CR-AVE biomass burning aerosol, organic-rich sulfate mixtures, and other particles of tropospheric origin still accounted for $40 \%$ of observed particles at $2.5 \mathrm{~km}$ above the tropopause $(\theta=440 \mathrm{~K})$. Murphy et al. (2007a) observed similar fractions for the mid-latitude and sub-tropical lower stratosphere. The continentally influenced Pre-AVE atmosphere again provides a contrasting picture at these high flight levels. The Pre-AVE lower stratosphere overwhelmingly consisted of tropospheric aerosol. At $2 \mathrm{~km}$ above the tropopause $(\theta=430 \mathrm{~K})$ over $90 \%$ of particles contained tropospheric signatures. Similarly, the relative abundance of meteoric particles that originated from the upper atmosphere was 7 times lower in the Pre-AVE lower stratosphere than for CR-AVE.

Stratospheric particles also descended into the troposphere. Stratospheric particles that were nearly pure sulfate were consistently found below the tropopause $(16.5-17 \mathrm{~km})$, their frequency decreasing with decreasing altitude. At $1 \mathrm{~km}$ below the tropopause, average particle acidity was between that of the TTL and the stratosphere. By $15 \mathrm{~km}$ particles of stratospheric origin were $<5 \%$ by number, and below this level stratospheric material did not contribute significantly to the overall aerosol composition. On average $\sim 1 \%$ of particles detected throughout the troposphere contained meteoric material.

\subsection{Implications for cirrus formation}

The clear air aerosol population of the TTL region was enriched in organic material and depleted in mineral dust. During CR-AVE, dust was 5 times more abundant from 4$12 \mathrm{~km}$ than in the TTL. Like acidic sulfate and aerosol MSA, vertical transport of dust into the TTL appears inefficient. 
Removal processes in the TTL may selectively deplete mineral dust. Mineral dust particles can act as efficient heterogeneous ice nuclei, forming ice crystals at ice saturation ratios as low as 1.1-1.3 (Archuleta et al., 2005; Mohler et al., 2006). However, dust particles in the TTL may be partially or fully coated with organic material that can inhibit freezing (Mohler et al., 2008). Unfortunately, TTL dust concentrations were too low to investigate trends in organic content.

Low levels of mineral dust were observed throughout the TTL. We can estimate the absolute concentration of dust particles in the TTL region by multiplying the fraction of particles identified as dust as a function of size by the total aerosol size distribution measured by FCAS. For CR-AVE an estimate for the average clear air dust concentration at $13-17 \mathrm{~km}$ is $\sim 5 \mathrm{~L}^{-1}$. The dust aerosols were almost exclusively submicron. Heterogeneous ice nuclei concentrations in the midlatitude and sub-tropical free troposphere are often on the order of $10 \mathrm{~L}^{-1}$ (DeMott et al., 2003; Prenni et al., 2007). Typical ice crystal concentrations within CR-AVE sub-visible cirrus were $20-100 \mathrm{~L}^{-1}$ (Lawson et al., 2008), which is an order of magnitude higher than the background dust concentration. If dust levels in the cloud-free TTL during CR-AVE are representative of steady-state conditions, then the formation of tropopause level cirrus either does not occur via ice nucleation on mineral dust or requires episodic direct injection of lower tropospheric aerosol.

During CR-AVE and Pre-AVE the WB-57 encountered several regions where high ice saturations $\left(S_{\text {ice }}>1.65\right)$ were near or exceeded levels required for homogeneous nucleation of sulfate/water aerosol (Jensen et al., 2005; Lawson et al., 2008). The vast majority of the high $S_{\text {ice }}$ periods occurred within or very near cirrus. Large relative uncertainties in upper tropospheric water vapor measurements, particularly within cirrus clouds, prevent exact knowledge of $S_{\text {ice. }}$ For the few high $S_{\text {ice }}$ segments observed in clear air, aerosol were chemically similar to segments with lower $S_{\text {ice }}$. $S_{\text {ice }}$ levels dictate that none of the aerosols in these regions could be effective heterogeneous ice nuclei, yet a few mineral dust particles were observed. It is likely that the most active ice nuclei had been removed at the lower TTL, and that the mineral dust present near the tropopause did not possess a significant advantage to ice crystal formation over homogeneous freezing.

Cziczo et al. (2009) demonstrated that lead-containing mineral dusts can be highly efficient heterogeneous ice nuclei. Aerosol lead is well mixed in the lower troposphere, consistent with a distributed source of $\sim 50 \mathrm{~nm}$ lead-rich particles that coagulate with background aerosols (Murphy et al., 2007b). Below $5 \mathrm{~km}$ during CR-AVE, lead was detected in $5-10 \%$ of aerosol particles, similar to previous measurements over North America (Murphy et al., 2007b). Lead was less abundant in the tropical upper tropospheric and lower stratosphere (detected consistently in $1-2 \%$ of all aerosols) and therefore less available to promote ice formation. Still, $19 \%$ of mineral dust particles above $5 \mathrm{~km}$ contained lead.
Recently, dry ammonium sulfate particles were demonstrated to be effective heterogeneous ice nuclei (Abbatt et al., 2006). PALMS results suggest that ammonium sulfate is likely to be abundant in the TTL. However, these neutralized sulfate aerosol were also internally mixed with organic material that may reduce their effectiveness as heterogeneous nuclei (Mohler et al., 2008). Detectable organic signatures were present on $>99 \%$ of particles sampled in the $13-16.5 \mathrm{~km}$ region, and $80 \%$ of sulfate-organic mixtures had organic mass fractions $>10 \%$. In previous PALMS studies, Cziczo et al. (2004a) showed that organic-rich aerosol did not freeze as readily as sulfate in free tropospheric clouds. Interestingly, DeMott et al. (2003) found that homogeneous freezing of aerosols with high oxidized organic and nitrate signals, similar to those found in the Pre-AVE and CR-AVE TTL (see Sects. 5.3.2 and 5.3.4), required noticeably higher saturations than sulfate particles.

There is recent evidence that ice nucleation can be inhibited under tropical tropospheric conditions for certain organic-rich particles that instead form highly viscous liquids or glasses (Murray, 2008; Zobrist et al., 2008). These authors performed experiments with both pure organic particles and sulfate-organic mixtures that may be representative of upper tropospheric aerosol. Purely inorganic aerosol did not form glasses under atmospheric conditions, whereas glass transitions were observed for pure organic and sulfateorganic mixtures at temperatures that depended mostly on organic molecular mass. Zobrist et al. contend that water uptake is inhibited for glassy particles at temperatures that comprise a large portion of the upper troposphere. However, it is important to note that cirrus clouds can form via nucleation of a small fraction $(<1$ in 100) of ambient aerosol. Low-organic particles such as stratospheric sulfuric acid and sulfate-meteoric mixtures are present at the $>5 \%$ level in the tropopause region where sub-visible cirrus frequently form. Their abundance in the tropical tropopause region suggests that organic glass-forming aerosols would not strongly inhibit the formation of tropopause level cirrus.

\section{Conclusions}

The Pre-AVE and CR-AVE campaigns provided a unique opportunity to investigate aerosol properties of the TTL, a relatively uncharacterized region of the lower atmosphere. We present tropical aerosol composition data using the PALMS single-particle mass spectrometer instrument from ground level to the lower stratosphere. Both campaigns took place during the Northern Hemisphere winter but probed very different atmospheric environments. Recent convection from South America strongly influenced all levels of the Pre-AVE troposphere, whereas CR-AVE was characterized by long range transport over the Pacific and maritime convection below $12 \mathrm{~km}$. The CR-AVE case may be more representative of the remote tropical troposphere. Although the source 
of convection largely defined regional aerosol properties, aerosols throughout the troposphere and stratosphere were externally mixed, having chemical signatures corresponding to a multitude of different emission or production sources.

Tropospheric aerosol chemical composition was also controlled by tropical dynamics. Vertical profiles of composition showed distinct transitions between levels of convective influence. Outside of regions strongly impacted by continental convection, the lower TTL boundary defined a transition in aerosol composition more abrupt than that at the tropopause, indicating that TTL aerosol properties were decoupled from lower regions.

In regions influenced by maritime convection, large accumulation mode particles composed of acidic sulfate and MSA were abundant. Transit times from convective systems were $\sim 5-10$ days, indicating that lofted material spent several days in the free troposphere without further boundary layer influence. During this time, nucleation and subsequent growth produced a population of sulfuric acid-rich accumulation mode aerosol. From the widespread observations of ultrafine particles in the CR-AVE convective region we can indirectly conclude that maritime convection in remote regions promotes new particle formation in the upper troposphere. This scenario is consistent with Kazil et al. (2006), who used a detailed nucleation mechanism to predict that the strongest aerosol production over oceans occurred in the tropical upper troposphere from convective lofting of aerosol precursors.

Continental convection from South America brought organic material directly into the TTL. Organic aerosols during Pre-AVE were consistent with biogenic SOA formation in the Amazon basin and/or conversion of VOCs aloft. Regardless of recent convective input, TTL aerosol composition was remarkably consistent. Accumulation mode particles were internal mixtures of highly oxidized organic material and partially or fully neutralized sulfate. Nitrogen levels were high, with contributions from both nitrate and ammonium. In general, TTL particle composition qualitatively resembled that of continental regions.

From these observations we can make several important statements regarding TTL aerosol sources. Outflow from recent ( $<14$ days) maritime convection only weakly contributed to TTL aerosol properties. Furthermore, the abrupt composition transitions at $12 \mathrm{~km}$ suggest that even nonconvective transport of some aerosol types into the lower TTL may be limited. These observations are surprising given that large scale trajectory models (Fueglistaler et al., 2005) indicate that the western Pacific provides an entry point for the TTL. On the other hand, continental convection injects aerosol and precursor material directly into the TTL and can even affect aerosol properties of the lower stratosphere. Although these injection events are sporadic and localized, aerosol residence times in the TTL are long compared to zonal transport. In this way intense continental convection may selectively seed the global TTL and lower stratosphere with primary and secondary aerosol material. Lastly, an important point regarding the unique TTL environment is that over the long residence times, aerosol processes such as composition-dependent removal, new particle formation, and gas phase accumulation will eventually act to decouple TTL aerosol properties from their sources, so that gas phase tracer analysis may not provide a reliable proxy of aerosol properties relevant to direct and indirect radiative forcing.

Tropical upper tropospheric aerosols freeze to form subvisible cirrus near the tropopause. The nucleation mechanism is unknown, but aerosol composition may play a critical role. Recent laboratory studies have revealed new mechanisms and obstacles to ice formation that may be directly applicable to the upper tropospheric aerosols presented here. Limited data from this study suggest that the tropical tropopause region is depleted in particles generally considered effective heterogeneous ice nuclei. In a future work we will investigate the composition of cirrus-forming aerosols in the tropical upper troposphere.

Acknowledgements. This work was funded by NOAA base and climate change programs as well as NASA funding for aircraft deployments. The authors gratefully acknowledge the efforts of the NASA mission scientists and coordinators, and the pilots and crew of the WB-57. We also thank Paul Lawson and Darrel Baumgardner and their instrument teams for use of the CPI, 2DS, and CAPS data to remove in-cloud flight segments. We are grateful to Daniel Cziczo, Troy Thornberry, Paula Hudson, Fred Moore, and Elliot Atlas for their valuable input.

Edited by: D. J. Cziczo

\section{References}

Abbatt, J. P. D., Benz, S., Cziczo, D. J., Kanji, Z., Lohmann, U., and Mohler, O.: Solid ammonium sulfate aerosols as ice nuclei: A pathway for cirrus cloud formation, Science, 313, 1770-1773, 2006.

Alcala, C. M. and Dessler, A. E.: Observations of deep convection in the tropics using the Tropical Rainfall Measuring Mission (TRMM) precipitation radar, J. Geophys. Res.-Atmos., 107, 4792, doi:10.1029/2002JD002457, 2002.

Archuleta, C. M., DeMott, P. J., and Kreidenweis, S. M.: Ice nucleation by surrogates for atmospheric mineral dust and mineral dust/sulfate particles at cirrus temperatures, Atmos. Chem. Phys., 5, 2617-2634, 2005,

http://www.atmos-chem-phys.net/5/2617/2005/.

Atkinson, R., Baulch, D. L., Cox, R. A., Crowley, J. N., Hampson, R. F., Hynes, R. G., Jenkin, M. E., Rossi, M. J., Troe, J., and IUPAC Subcommittee: Evaluated kinetic and photochemical data for atmospheric chemistry: Volume II - gas phase reactions of organic species, Atmos. Chem. Phys., 6, 3625-4055, 2006, http://www.atmos-chem-phys.net/6/3625/2006/.

Bigg, E. K.: Ammonium Compounds in Stratospheric Aerosols, Tellus, 38B, 62-66, 1986.

Blake, N. J., Blake, D. R., Simpson, I. J., Meinardi, S., Swanson, A. L., Lopez, J. P., Katzenstein, A. S., Barletta, B., Shirai, T., Atlas, E., Sachse, G., Avery, M., Vay, S., Fuelberg, H. E., Kiley, 
C. M., Kita, K., and Rowland, F. S.: NMHCs and halocarbons in Asian continental outflow during the Transport and Chemical Evolution over the Pacific (TRACE-P) Field Campaign: Comparison with PEM-West B, J. Geophys. Res.-Atmos., 108, 8806, doi:10.1029/2002JD003367, 2003a.

Blake, N. J., Blake, D. R., Swanson, A. L., Atlas, E., Flocke, F., and Rowland, F. S.: Latitudinal, vertical, and seasonal variations of $\mathrm{C}-1-\mathrm{C}-4$ alkyl nitrates in the troposphere over the Pacific Ocean during PEM-Tropics A and B: Oceanic and continental sources, J. Geophys. Res.-Atmos., 108, 8242, doi:10.1029/2001JD001444, 2003b.

Brock, C. A., Hamill, P., Wilson, J. C., Jonsson, H. H., and Chan, K. R.: Particle Formation in the Upper Tropical Troposphere a Source of Nuclei for the Stratospheric Aerosol, Science, 270, 1650-1653, 1995.

Brock, C. A., Schroder, F., Karcher, B., Petzold, A., Busen, R., and Fiebig, M.: Ultrafine particle size distributions measured in aircraft exhaust plumes, J. Geophys. Res.-Atmos., 105, 2655526567, 2000.

Brock, C. A., Hudson, P. K., Lovejoy, E. R., Sullivan, A., Nowak, J. B., Huey, L. G., Cooper, O. R., Cziczo, D. J., de Gouw, J., Fehsenfeld, F. C., Holloway, J. S., Hubler, G., Lafleur, B. G., Murphy, D. M., Neuman, J. A., Nicks, D. K., Orsini, D. A., Parrish, D. D., Ryerson, T. B., Tanner, D. J., Warneke, C., Weber, R. J., and Wilson, J. C.: Particle characteristics following cloud-modified transport from Asia to North America, J. Geophys. Res.-Atmos., 109, D23S26, doi:10.1029/2003JD004198, 2004.

Burgess, A. B., Dudhia, A., Grainger, R. G., and Stevenson, D.: Progress in tropospheric ammonia retrieval from the MIPAS satellite instrument, Adv. Space. Res., 37, 2218-2221, 2006.

Claeys, M., Graham, B., Vas, G., Wang, W., Vermeylen, R., Pashynska, V., Cafmeyer, J., Guyon, P., Andreae, M. O., Artaxo, P., and Maenhaut, W.: Formation of secondary organic aerosols through photooxidation of isoprene, Science, 303, 1173-1176, 2004.

Cziczo, D. J., Thomson, D. S., and Murphy, D. M.: Ablation, flux, and atmospheric implications of meteors inferred from stratospheric aerosol, Science, 291, 1772-1775, 2001.

Cziczo, D. J., DeMott, P. J., Brooks, S. D., Prenni, A. J., Thomson, D. S., Baumgardner, D., Wilson, J. C., Kreidenweis, S. M., and Murphy, D. M.: Observations of organic species and atmospheric ice formation, Geophys. Res. Lett., 31, L12116, doi:10.1029/2004GL019822, 2004a.

Cziczo, D. J., Murphy, D. M., Hudson, P. K., and Thomson, D. S.: Single particle measurements of the chemical composition of cirrus ice residue during CRYSTAL-FACE, J. Geophys. Res.Atmos., 109, D04201, doi:10.1029/2003JD004032, 2004b.

Cziczo, D. J., Stetzer, O., Worringen, A., Ebert, M., Weinbruch, S., Kamphus, M., Gallavardin, S. J., Curtius, J., Borrmann, S., Froyd, K. D., Mertes, S., Mohler, O., and Lohmann, U.: Inadvertent climate modification due to anthropogenic lead, Nature Geosci., 2, 333-336, 2009.

Danielsen, E. F.: Insitu Evidence of Rapid, Vertical, Irreversible Transport of Lower Tropospheric Air into the Lower Tropical Stratosphere by Convective Cloud Turrets and by Larger-Scale Upwelling in Tropical Cyclones, J .Geophys. Res.-Atmos., 98, 8665-8681, 1993.

Davis, D., Chen, G., Bandy, A., Thornton, D., Eisele, F., Mauldin, L., Tanner, D., Lenschow, D., Fuelberg, H., Huebert, B., Heath,
J., Clarke, A., and Blake, D.: Dimethyl sulfide oxidation in the equatorial Pacific: Comparison of model simulations with field observations for DMS, SO2, H2SO4(g), MSA(g), MS, and NSS, J. Geophys. Res.-Atmos., 104, 5765-5784, 1999.

DeMore, W. B.: Chemical kinetics and photochemical data for use in stratospheric modeling evaluation number 15, National Aeronautics and Space Administration Jet Propulsion Laboratory, http://jpldataeval.jpl.nasa.gov/, 2006.

DeMott, P. J., Cziczo, D. J., Prenni, A. J., Murphy, D. M., Kreidenweis, S. M., Thomson, D. S., Borys, R., and Rogers, D. C.: Measurements of the concentration and composition of nuclei for cirrus formation, P. Natl. Acad. Sci. USA, 100, 14655-14660, 2003.

Dentener, F. J. and Crutzen, P. J.: A 3-Dimensional Model of the Global Ammonia Cycle, J. Atmos. Chem., 19, 331-369, 1994.

Dessler, A. E. and Yang, P.: The distribution of tropical thin cirrus clouds inferred from terra MODIS data, J. Climate, 16, 12411247, 2003.

Dessler, A. E., Palm, S. P., Hart, W. D., and Spinhirne, J. D.: Tropopause-level thin cirrus coverage revealed by ICESat/Geoscience Laser Altimeter System, J. Geophys. Res.Atmos., 111, D08203, doi:10.1029/2005JD006586, 2006.

Dibb, J. E., Talbot, R. W., Scheuer, E. M., Blake, D. R., Blake, N. J., Gregory, G. L., Sachse, G. W., and Thornton, D. C.: Aerosol chemical composition and distribution during the Pacific Exploratory Mission (PEM) Tropics, J. Geophys. Res.-Atmos., 104, 5785-5800, 1999.

Dibb, J. E., Talbot, R. W., Scheuer, E. M., Seid, G., Avery, M. A., and Singh, H. B.: Aerosol chemical composition in Asian continental outflow during the TRACE-P campaign: Comparison with PEM-West B, J. Geophys. Res.-Atmos., 108, 8815, doi:10.1029/2002JD003111, 2003.

Ekman, A. M. L., Wang, C., Strom, J., and Krejci, R.: Explicit simulation of aerosol physics in a cloud-resolving model: Aerosol transport and processing in the free troposphere, J. Atmos. Sci., 63, 682-696, 2006.

Ervens, B., Feingold, G., Frost, G. J., and Kreidenweis, S. M.: A modeling study of aqueous production of dicarboxylic acids: 1. Chemical pathways and speciated organic mass production, J. Geophys. Res.-Atmos., 109, D15205, doi:10.1029/2003JD004387, 2004.

Falkovich, A. H., Graber, E. R., Schkolnik, G., Rudich, Y., Maenhaut, W., and Artaxo, P.: Low molecular weight organic acids in aerosol particles from Rondônia, Brazil, during the biomassburning, transition and wet periods, Atmos. Chem. Phys., 5, 781797, 2005, http://www.atmos-chem-phys.net/5/781/2005/.

Folkins, I., Loewenstein, M., Podolske, J., Oltmans, S. J., and Proffitt, M.: A barrier to vertical mixing at $14 \mathrm{~km}$ in the tropics: Evidence from ozonesondes and aircraft measurements, J. Geophys. Res.-Atmos., 104, 22095-22102, 1999.

Folkins, I., Oltmans, S. J., and Thompson, A. M.: Tropical convective outflow and near surface equivalent potential temperatures, Geophys. Res. Lett., 27, 2549-2552, 2000.

Folkins, I.: Origin of lapse rate changes in the upper tropical troposphere, J. Atmos. Sci., 59, 992-1005, 2002.

Fueglistaler, S., Bonazzola, M., Haynes, P. H., and Peter, T.: Stratospheric water vapor predicted from the Lagrangian temperature history of air entering the stratosphere in the tropics, J. Geophys. Res.-Atmos., 110, D08107, doi:10.1029/2004JD005516, 2005. 
Fuzzi, S., Decesari, S., Facchini, M. C., Cavalli, F., Emblico, L., Mircea, M., Andreae, M. O., Trebs, I., Hoffer, A., Guyon, P., Artaxo, P., Rizzo, L. V., Lara, L. L., Pauliquevis, T., Maenhaut, W., Raes, N., Chi, X. G., Mayol-Bracero, O. L., Soto-Garcia, L. L., Claeys, M., Kourtchev, I., Rissler, J., Swietlicki, E., Tagliavini, E., Schkolnik, G., Falkovich, A. H., Rudich, Y., Fisch, G., and Gatti, L. V.: Overview of the inorganic and organic composition of size-segregated aerosol in Rondonia, Brazil, from the biomass-burning period to the onset of the wet season, J. Geophys. Res.-Atmos., 112, D01201, doi:10.1029/2005JD006741, 2007.

Gettelman, A., Salby, M. L., and Sassi, F.: Distribution and influence of convection in the tropical tropopause region, J. Geophys. Res.-Atmos., 107, 4080, doi:10.1029/2001JD001048, 2002.

Gettelman, A., Forster, P. M. D., Fujiwara, M., Fu, Q., Vomel, H., Gohar, L. K., Johanson, C., and Ammerman, M.: Radiation balance of the tropical tropopause layer, J. Geophys. Res.-Atmos., 109, D07103, doi:10.1029/2003JD004190, 2004.

Gondwe, M., Krol, M., Gieskes, W., Klaassen, W., and de Baar, H.: The contribution of ocean-leaving DMS to the global atmospheric burdens of DMS, MSA, SO2, and NSS SO4=, Global Biogeochem. Cycles, 17, 1056, doi:10.1029/2002GB001937, 2003.

Graham, B., Guyon, P., Maenhaut, W., Taylor, P. E., Ebert, M., Matthias-Maser, S., Mayol-Bracero, O. L., Godoi, R. H. M., Artaxo, P., Meixner, F. X., Moura, M. A. L., Rocha, C. H. E. D., Van Grieken, R., Glovsky, M. M., Flagan, R. C., and Andreae, M. O.: Composition and diurnal variability of the natural Amazonian aerosol, J. Geophys. Res.-Atmos., 108, 4765, doi:10.1029/2003JD004049, 2003a.

Graham, B., Guyon, P., Taylor, P. E., Artaxo, P., Maenhaut, W., Glovsky, M. M., Flagan, R. C., and Andreae, M. O.: Organic compounds present in the natural Amazonian aerosol: Characterization by gas chromatography-mass spectrometry, J. Geophys. Res.-Atmos., 108, 4766, doi:10.1029/2003JD003990, 2003 b.

Gras, J. L.: Change in Nature of Stratospheric Aerosol Collected at 34-Degrees-S, Nature, 271, 231-232, 1978.

Highwood, E. J. and Hoskins, B. J.: The tropical tropopause, Q. J. Roy. Meteorol. Soc., 124, 1579-1604, 1998.

Holton, J. R. and Gettelman, A.: Horizontal transport and the dehydration of the stratosphere, Geophys. Res. Lett., 28, 2799-2802, 2001.

Hong, G., Yang, P., Gao, B. C., Baum, B. A., Hu, Y. X., King, M. D., and Platnick, S.: High cloud properties from three years of MODIS Terra and Aqua collection-4 data over the Tropics, J. Appl. Meteorol. Clim., 46, 1840-1856, 2007.

Hudson, P. K., Murphy, D. M., Cziczo, D. J., Thomson, D. S., de Gouw, J. A., Warneke, C., Holloway, J., Jost, J. R., and Hubler, G.: Biomass-burning particle measurements: Characteristic composition and chemical processing, J. Geophys. Res.Atmos., 109, D23S27, doi:10.1029/2003JD004398, 2004.

Iraci, L. T., Essin, A. M., and Golden, D. M.: Solubility of methanol in low-temperature aqueous sulfuric acid and implications for atmospheric particle composition, J. Phys. Chem. A., 106, 40544060, 2002.

Iraci, L. T., Riffel, B. G., Robinson, C. B., Michelsen, R. R., and Stephenson, R. M.: The acid catalyzed nitration of methanol: formation of methyl nitrate via aerosol chemistry, J. Atmos. Chem., 58, 253-266, 2007.
Jensen, E. and Pfister, L.: Transport and freeze-drying in the tropical tropopause layer, J. Geophys. Res.-Atmos., 109, D02207, doi:10.1029/2003JD004022, 2004.

Jensen, E. J., Toon, O. B., Pfister, L., and Selkirk, H. B.: Dehydration of the upper troposphere and lower stratosphere by subvisible cirrus clouds near the tropical tropopause, Geophys. Res. Lett., 23, 825-828, 1996.

Jensen, E. J., Smith, J. B., Pfister, L., Pittman, J. V., Weinstock, E. M., Sayres, D. S., Herman, R. L., Troy, R. F., Rosenlof, K., Thompson, T. L., Fridlind, A. M., Hudson, P. K., Cziczo, D. J., Heymsfield, A. J., Schmitt, C., and Wilson, J. C.: Ice supersaturations exceeding $100 \%$ at the cold tropical tropopause: implications for cirrus formation and dehydration, Atmos. Chem. Phys., 5, 851-862, 2005, http://www.atmos-chem-phys.net/5/851/2005/.

Jonsson, H. H., Wilson, J. C., Brock, C. A., Knollenberg, R. G., Newton, R., Dye, J. E., Baumgardner, D., Borrmann, S., Ferry, G. V., Pueschel, R., Woods, D. C., and Pitts, M. C.: Performance of a Focused Cavity Aerosol Spectrometer for Measurements in the Stratosphere of Particle-Size in the 0.06-2.0-Mu-MDiameter Range, J. Atmos. Ocean. Tech., 12, 115-129, 1995.

Kavouras, I. G. and Stephanou, E. G.: Direct evidence of atmospheric secondary organic aerosol formation in forest atmosphere through heteromolecular nucleation, Environ. Sci. Technol., 36, 5083-5091, 2002.

Kazil, J., Lovejoy, E. R., Barth, M. C., and O’Brien, K.: Aerosol nucleation over oceans and the role of galactic cosmic rays, Atmos. Chem. Phys., 6, 4905-4924, 2006, http://www.atmos-chem-phys.net/6/4905/2006/.

Kelly, K. K., Proffitt, M. H., Chan, K. R., Loewenstein, M., Podolske, J. R., Strahan, S. E., Wilson, J. C., and Kley, D.: Water-Vapor and Cloud Water Measurements over Darwin during the Step 1987 Tropical Mission, J. Geophys. Res.-Atmos., 98, 8713-8723, 1993.

Kesselmeier, J., Kuhn, U., Rottenberger, S., Biesenthal, T., Wolf, A., Schebeske, G., Andreae, M. O., Ciccioli, P., Brancaleoni, E., Frattoni, M., Oliva, S. T., Botelho, M. L., Silva, C. M. A., and Tavares, T. M.: Concentrations and species composition of atmospheric volatile organic compounds (VOCs) as observed during the wet and dry season in Rondonia (Amazonia), J. Geophys. Res.-Atmos., 107, 8053, doi:10.1029/2000JD000267, 2002.

Knollenberg, R. G., Kelly, K., and Wilson, J. C.: Measurements of High Number Densities of Ice Crystals in the Tops of Tropical Cumulonimbus, J. Geophys. Res.-Atmos., 98, 8639-8664, 1993.

Kritz, M. A., Rosner, S. W., Kelly, K. K., Loewenstein, M., and Chan, K. R.: Radon Measurements in the Lower Tropical Stratosphere - Evidence for Rapid Vertical Transport and Dehydration of Tropospheric Air, J. Geophys. Res.-Atmos., 98, 8725-8736, 1993.

Kroll, J. H., Ng, N. L., Murphy, S. M., Flagan, R. C., and Seinfeld, J. H.: Secondary organic aerosol formation from isoprene photooxidation, Environ. Sci. Technol., 40, 1869-1877, 2006.

Kupper, C., Thuburn, J., Craig, G. C., and Birner, T.: Mass and water transport into the tropical stratosphere: A cloudresolving simulation, J. Geophys. Res.-Atmos., 109, D10111, doi:10.1029/2004JD004541, 2004.

Lawson, R. P., Pilson, B., Baker, B., Mo, Q., Jensen, E., Pfister, L., and Bui, P.: Aircraft measurements of microphysical properties of subvisible cirrus in the tropical tropopause layer, Atmos. 
Chem. Phys., 8, 1609-1620, 2008,

http://www.atmos-chem-phys.net/8/1609/2008/.

Lee, S. H., Murphy, D. M., Thomson, D. S., and Middlebrook, A. M.: Nitrate and oxidized organic ions in single particle mass spectra during the 1999 Atlanta Supersite Project, J. Geophys. Res.-Atmos., 108(D7), 8417, doi:10.1029/2001JD001455, 2003a.

Lee, S. H., Reeves, J. M., Wilson, J. C., Hunton, D. E., Viggiano, A. A., Miller, T. M., Ballenthin, J. O., and Lait, L. R.: Particle formation by ion nucleation in the upper troposphere and lower stratosphere, Science, 301, 1886-1889, 2003b.

Lee, Y. N., Weber, R., Ma, Y., Orsini, D., Maxwell-Meier, K., Blake, D., Meinardi, S., Sachse, G., Harward, C., Chen, T. Y., Thornton, D., Tu, F. H., and Bandy, A.: Airborne measurement of inorganic ionic components of fine aerosol particles using the particle-into-liquid sampler coupled to ion chromatography technique during ACE-Asia and TRACE-P, J. Geophys. Res.-Atmos., 108, 8646, doi:10.1029/2002JD003265, 2003.

Lim, H. J., Carlton, A. G., and Turpin, B. J.: Isoprene forms secondary organic aerosol through cloud processing: Model simulations, Environ. Sci. Technol., 39, 4441-4446, 2005.

Liu, C. T. and Zipser, E. J.: Global distribution of convection penetrating the tropical tropopause, J. Geophys. Res.-Atmos., 110, D23104, doi:10.1029/2005JD006063, 2005.

Liu, C. T.: Geographical and seasonal distribution of tropical tropopause thin clouds and their relation to deep convection and water vapor viewed from satellite measurements, J. Geophys. Res.-Atmos., 112, D09205, doi:10.1029/2006JD007479, 2007.

Lovejoy, E. R., Curtius, J., and Froyd, K. D.: Atmospheric ioninduced nucleation of sulfuric acid and water, J. Geophys. Res.Atmos., 109, D08204, doi:10.1029/2003jd004460, 2004.

Luo, B. P., Peter, T., Fueglistaler, S., Wernli, H., Wirth, M., Kiemle, C., Flentje, H., Yushkov, V. A., Khattatov, V., Rudakov, V., Thomas, A., Borrmann, S., Toci, G., Mazzinghi, P., Beuermann, J., Schiller, C., Cairo, F., Di Donfrancesco, G., Adriani, A., Volk, C. M., Strom, J., Noone, K., Mitev, V., MacKenzie, R. A., Carslaw, K. S., Trautmann, T., Santacesaria, V., and Stefanutti, L.: Dehydration potential of ultrathin clouds at the tropical tropopause, Geophys. Res. Lett., 30, 1557, doi:10.1029/2002GL016737, 2003.

Ma, Y., Weber, R. J., Maxwell-Meier, K., Orsini, D. A., Lee, Y. N., Huebert, B. J., Howell, S. G., Bertram, T., Talbot, R. W., Dibb, J. E., and Scheuer, E.: Intercomparisons of airborne measurements of aerosol ionic chemical composition during TRACE-P and ACE-Asia, J. Geophys. Res.-Atmos., 109, D15S06, doi:10.1029/2003JD003673, 2004.

McFarquhar, G. M., Heymsfield, A. J., Spinhirne, J., and Hart, B.: Thin and subvisual tropopause tropical cirrus: Observations and radiative impacts, J. Atmos. Sci., 57, 1841-1853, 2000.

Michelsen, R. R., Staton, S. J. R., and Iraci, L. T.: Uptake and dissolution of gaseous ethanol in sulfuric acid, J. Phys. Chem. A, 110, 6711-6717, 2006.

Möhler, O., Field, P. R., Connolly, P., Benz, S., Saathoff, H., Schnaiter, M., Wagner, R., Cotton, R., Krämer, M., Mangold, A., and Heymsfield, A. J.: Efficiency of the deposition mode ice nucleation on mineral dust particles, Atmos. Chem. Phys., 6, 30073021, 2006, http://www.atmos-chem-phys.net/6/3007/2006/.

Mohler, O., Benz, S., Saathoff, H., Schnaiter, M., Wagner, R., Schneider, J., Walter, S., Ebert, V., and Wagner, S.: The ef- fect of organic coating on the heterogeneous ice nucleation efficiency of mineral dust aerosols, Environ. Res. Lett., 3, 025007, doi:10.1088/1748-9326/3/2/025007, 2008.

Munger, J. W., Tiller, C., and Hoffmann, M. R.: Identification of Hydroxymethanesulfonate in Fog Water, Science, 231, 247-249, 1986.

Murphy, D. M., Middlebrook, A. M., and Warshawsky, M.: Cluster analysis of data from the Particle Analysis by Laser Mass Spectrometry (PALMS) instrument, Aerosol Sci. Tech., 37, 382-391, 2003.

Murphy, D. M., Cziczo, D. J., Froyd, K. D., Hudson, P. K., Matthew, B. M., Middlebrook, A. M., Peltier, R. E., Sullivan, A., Thomson, D. S., and Weber, R. J.: Single-particle mass spectrometry of tropospheric aerosol particles, J. Geophys. Res.-Atmos., 111, D23S32, doi:10.1029/2006JD007340, 2006.

Murphy, D. M., Cziczo, D. J., Hudson, P. K., and Thomson, D. S.: Carbonaceous material in aerosol particles in the lower stratosphere and tropopause region, J. Geophys. Res.-Atmos., 112, D04203, doi:10.1029/2006JD007297, 2007a.

Murphy, D. M., Hudson, P. K., Cziczo, D. J., Gallavardin, S., Froyd, K. D., Johnston, M. V., Middlebrook, A. M., Reinard, M. S., Thomson, D. S., Thornberry, T., and Wexler, A. S.: Distribution of lead in single atmospheric particles, Atmos. Chem. Phys., 7, 3195-3210, 2007b,

http://www.atmos-chem-phys.net/7/3195/2007/.

Murray, B. J.: Inhibition of ice crystallisation in highly viscous aqueous organic acid droplets, Atmos. Chem. Phys., 8, 54235433, 2008, http://www.atmos-chem-phys.net/8/5423/2008/.

Ng, N. L., Chhabra, P. S., Chan, A. W. H., Surratt, J. D., Kroll, J. H., Kwan, A. J., McCabe, D. C., Wennberg, P. O., Sorooshian, A., Murphy, S. M., Dalleska, N. F., Flagan, R. C., and Seinfeld, J. H.: Effect of $\mathrm{NO}_{\mathrm{x}}$ level on secondary organic aerosol (SOA) formation from the photooxidation of terpenes, Atmos. Chem. Phys., 7, 5159-5174, 2007,

http://www.atmos-chem-phys.net/7/5159/2007/.

Ng, N. L., Kwan, A. J., Surratt, J. D., Chan, A. W. H., Chhabra, P. S., Sorooshian, A., Pye, H. O. T., Crounse, J. D., Wennberg, P. O., Flagan, R. C., and Seinfeld, J. H.: Secondary organic aerosol (SOA) formation from reaction of isoprene with nitrate radicals (NO3), Atmos. Chem. Phys., 8, 4117-4140, 2008, http://www.atmos-chem-phys.net/8/4117/2008/.

Nguyen, H. N., Martinsson, B. G., Wagner, J. B., Carlemalm, E., Ebert, M., Weinbruch, S., Brenninkmeijer, C. A. M., Heintzenberg, J., Hermann, M., Schuck, T., van Velthoven, P. F. J., and Zahn, A.: Chemical composition and morphology of individual aerosol particles from a CARIBIC flight at $10 \mathrm{~km}$ altitude between 50 degrees $\mathrm{N}$ and 30 degrees S, J. Geophys. Res.-Atmos., 113, D23209, doi:10.1029/2008JD009956, 2008.

Nozière, B., Dziedzic, P., and Córdova, A.: Common inorganic ions are efficient catalysts for organic reactions in atmospheric aerosols and other natural environments, Atmos. Chem. Phys. Discuss., 9, 1-21, 2009,

http://www.atmos-chem-phys-discuss.net/9/1/2009/.

Park, S., Jimnez, R., Daube, B. C., Pfister, L., Conway, T. J., Gottlieb, E. W., Chow, V. Y., Curran, D. J., Matross, D. M., Bright, A., Atlas, E. L., Bui, T. P., Gao, R.-S., Twohy, C. H., and Wofsy, S. C.: The $\mathrm{CO}_{2}$ tracer clock for the Tropical Tropopause Layer, Atmos. Chem. Phys., 7, 3989-4000, 2007, http://www.atmos-chem-phys.net/7/3989/2007/. 
Peltier, R. E., Sullivan, A. P., Weber, R. J., Brock, C. A., Wollny, A. G., Holloway, J. S., de Gouw, J. A., and Warneke, C.: Fine aerosol bulk composition measured on WP-3D research aircraft in vicinity of the Northeastern United States results from NEAQS, Atmos. Chem. Phys., 7, 3231-3247, 2007, http://www.atmos-chem-phys.net/7/3231/2007/.

Pfister, L., Chan, K. R., Bui, T. P., Bowen, S., Legg, M., Gary, B., Kelly, K., Proffitt, M., and Starr, W.: Gravity-Waves Generated by a Tropical Cyclone during the Step Tropical Field Program a Case-Study, J. Geophys. Res.-Atmos., 98, 8611-8638, 1993.

Pfister, L., Selkirk, H. B., Jensen, E. J., Schoeberl, M. R., Toon, O. B., Browell, E. V., Grant, W. B., Gary, B., Mahoney, M. J., Bui, T. V., and Hintsa, E.: Aircraft observations of thin cirrus clouds near the tropical tropopause, J. Geophys. Res.-Atmos., 106, 9765-9786, 2001.

Prenni, A. J., DeMott, P. J., Twohy, C., Poellot, M. R., Kreidenweis, S. M., Rogers, D. C., Brooks, S. D., Richardson, M. S., and Heymsfield, A. J.: Examinations of ice formation processes in Florida cumuli using ice nuclei measurements of anvil ice crystal particle residues, J. Geophys. Res.-Atmos., 112, D10221, doi:10.1029/2006JD007549, 2007.

Rosenfield, J. E., Considine, D. B., Schoeberl, M. R., and Browell, E. V.: The impact of subvisible cirrus clouds near the tropical tropopause on stratospheric water vapor, Geophys. Res. Lett., 25, 1883-1886, 1998.

Rudich, Y.: Laboratory perspectives on the chemical transformations of organic matter in atmospheric particles, Chem. Rev., 103, 5097-5124, 2003.

Schoeberl, M. R. and Sparling, L. C.: Trajectory modeling, in: Diagnostic tools in atmospheric physics, vol. 124, edited by: Fiocco, G. and Visconti, G., I O S Press, Inc, 289-306, 1995.

Singh, H. B., Salas, L. J., Chatfield, R. B., Czech, E., Fried, A., Walega, J., Evans, M. J., Field, B. D., Jacob, D. J., Blake, D., Heikes, B., Talbot, R., Sachse, G., Crawford, J. H., Avery, M. A., Sandholm, S., and Fuelberg, H.: Analysis of the atmospheric distribution, sources, and sinks of oxygenated volatile organic chemicals based on measurements over the Pacific during TRACE-P, J. Geophys. Res.-Atmos., 109, D15S07, doi:10.1029/2003JD003883, 2004.

Sorooshian, A., Lu, M. L., Brechtel, F. J., Jonsson, H., Feingold, G., Flagan, R. C., and Seinfeld, J. H.: On the source of organic acid aerosol layers above clouds, Environ. Sci. Technol., 41, 46474654, 2007a.

Sorooshian, A., Ng, N. L., Chan, A. W. H., Feingold, G., Flagan, R. C., and Seinfeld, J. H.: Particulate organic acids and overall water-soluble aerosol composition measurements from the 2006 Gulf of Mexico Atmospheric Composition and Climate Study (GoMACCS), J. Geophys. Res.-Atmos., 112, D13201, doi:10.1029/2007JD008537, 2007b.
Thomson, D. S., Schein, M. E., and Murphy, D. M.: Particle analysis by laser mass spectrometry WB-57F instrument overview, Aerosol Sci. Tech., 33, 153-169, 2000.

Tie, X. X., Zhang, R. Y., Brasseur, G., and Lei, W. F.: Global $\mathrm{NO}_{\mathrm{X}}$ production by lightning, J. Atmos. Chem., 43, 61-74, 2002.

Toracinta, E. R., Cecil, D. J., Zipser, E. J., and Nesbitt, S. W.: Radar, passive microwave, and lightning characteristics of precipitating systems in the tropics, Mon. Weather Rev., 130, 802-824, 2002.

von Glasow, R. and Crutzen, P. J.: Model study of multiphase DMS oxidation with a focus on halogens, Atmos. Chem. Phys., 4, 589608, 2004, http://www.atmos-chem-phys.net/4/589/2004/.

Wang, P. H., Minnis, P., McCormick, M. P., Kent, G. S., and Skeens, K. M.: A 6-year climatology of cloud occurrence frequency from stratospheric aerosol and gas experiment II observations (19851990), J. Geophys. Res.-Atmos., 101, 29407-29429, 1996.

Wennberg, P. O., Hanisco, T. F., Jaegle, L., Jacob, D. J., Hintsa, E. J., Lanzendorf, E. J., Anderson, J. G., Gao, R. S., Keim, E. R., Donnelly, S. G., Del Negro, L. A., Fahey, D. W., McKeen, S. A., Salawitch, R. J., Webster, C. R., May, R. D., Herman, R. L., Proffitt, M. H., Margitan, J. J., Atlas, E. L., Schauffler, S. M., Flocke, F., McElroy, C. T., and Bui, T. P.: Hydrogen radicals, nitrogen radicals, and the production of O-3 in the upper troposphere, Science, 279, 49-53, 1998.

Whiteaker, J. R. and Prather, K. A.: Hydroxymethanesulfonate as a tracer for fog processing of individual aerosol particles, Atmos. Environ., 37, 1033-1043, 2003.

Wilson, J. C., Lee, S.-H., Reeves, J. M., Brock, C. A., Jonsson, H. H., Lafleur, B. G., Loewenstein, M., Podolske, J., Atlas, E., Boering, K., Toon, G., Fahey, D., Bui, T. P., Diskin, G., and Moore, F.: Steady-state aerosol distributions in the extra-tropical, lower stratosphere and the processes that maintain them, Atmos. Chem. Phys., 8, 6617-6626, 2008, http://www.atmos-chem-phys.net/8/6617/2008/.

Winker, D. M. and Trepte, C. R.: Laminar cirrus observed near the tropical tropopause by LITE, Geophys. Res. Lett., 25, 33513354, 1998.

Yang, Q., Fu, Q., and Hu, Y.: Radiative impacts of clouds in the tropical tropopause layer, J. Geophys. Res.-Atmos., submitted, 2009.

Zhu, L., Nenes, A., Wine, P. H., and Nicovich, J. M.: Effects of aqueous organosulfur chemistry on particulate methanesulfonate to non-sea salt sulfate ratios in the marine atmosphere, J. Geophys. Res.-Atmos., 111, D05316, doi:10.1029/2005JD006326, 2006.

Zobrist, B., Marcolli, C., Pedernera, D. A., and Koop, T.: Do atmospheric aerosols form glasses?, Atmos. Chem. Phys., 8, 52215244, 2008, http://www.atmos-chem-phys.net/8/5221/2008/. 